\title{
The role of non-coding RNAs in male sex determination and differentiation
}

\author{
Raphael H Rastetter, Craig A Smith and Dagmar Wilhelm \\ Department of Anatomy and Developmental Biology, Monash University, Clayton, Victoria 3800, Australia
}

Correspondence should be addressed to D Wilhelm; Email: dagmar.wilhelm@monash.edu or to C A Smith; Email: craig.smith@monash.edu

\begin{abstract}
A complex network of gene regulation and interaction drives male sex determination and differentiation. While many important proteincoding genes that are necessary for proper male development have been identified, many disorders in human sex development are still unexplained at the molecular level. This suggests that key factors and regulatory mechanisms are still unknown. In recent years, extensive data have shown that different classes of non-coding RNAs (ncRNAs) play a role in almost all developmental and physiological pathways. Here we review what is known about their role in male sex determination and differentiation not only in mammals, but also other species. While for some processes a key role for ncRNA has been identified, we are still far from having a complete picture.
\end{abstract}

Reproduction (2015) 150 R93-R107

\section{Introduction}

Non-coding RNAs (ncRNAs), in a broad sense, are RNA molecules that, in contrast to messenger RNAs (mRNAs), do not code for proteins. However, more recently, 'ncRNAs' has been more specifically used for RNAs that not only have no protein-coding potential but also have some kind of regulatory function. These regulatory ncRNAs can be further divided, rather arbitrarily, into small RNAs, which are shorter than 200 nucleotides (nt), and long ncRNAs (IncRNAs) with a length above 200 nt. Small ncRNAs are not only defined by their size but also their association with members of the Argonaute (AGO) protein family, for which two clades can be distinguished, the AGO and the PIWI subfamily. Small regulatory ncRNAs can be further sub-divided into microRNAs (miRNAs), endogenous small interfering RNAs (endo-siRNAs), and PIWI-associated RNAs (piRNAs) based on their size, function, mode of action and the AGO protein they bind to (Farazi et al. 2008, Kim et al. 2009).

At the forefront of investigations have been miRNAs, which regulate gene expression primarily post-transcriptionally through mRNA destabilization and/or inhibition of translation (Pillai 2005, Filipowicz et al. 2008, Carthew \& Sontheimer 2009). Most miRNAs are transcribed by RNA polymerase II and are processed by Drosha in association with DGCR8 in the nucleus, giving rise to a short hairpin that is exported from the nucleus by exportin 5, and further processed in the cytoplasm by Dicer to give rise to a 21-23-nt long
miRNA duplex. One strand of the duplex is then incorporated into the AGO-containing RNA-induced silencing complex (RISC) and mediates sequencespecific binding to target mRNAs, which are subsequently degraded and/or translationally silenced (Farazi et al. 2008, Kim et al. 2009).

Hundreds of miRNAs are expressed in the developing testis in mammals (Yang et al. 2013), and their general role has been analysed using mice lacking Dicer, specifically in somatic or germ cells of the developing testis. Mice homozygous for Dicer 1 deletion in either germ or somatic cells during embryogenesis lead to male infertility due to multiple cumulative defects resulting in the absence of functional sperm (Hayashi et al. 2008, Maatouk et al. 2008, Papaioannou et al. 2009, Huang \& Yao 2010, Zimmermann et al. 2014), demonstrating that miRNAs are important for proper testis development and function. However, from these experiments it remains unclear which specific miRNAs play important roles in these processes. Progress has been made to identify some of these, which we will discuss in more detail below.

In addition to miRNAs, endo-siRNAs also associate with AGO proteins. These small RNAs are derived from long, perfectly complementary double-stranded RNAs that are formed through sense-antisense transcript pairs, long stem-loop structures and transposon transcripts (Golden et al. 2008). Their processing is Drosha/DGCR8 independent but requires multiple Dicer cleavages along the precursor RNA (Watanabe et al. 2006, Tam et al. 2008). For quite some time it was believed that 
endo-siRNAs do not exist in vertebrates, because Dicer was believed to act exclusively in the cytoplasm, and cytoplasmic long dsRNAs trigger a strong immune response though protein kinase $R$. However, nuclear action of Dicer has been demonstrated recently, and endo-siRNA expression has been detected mainly in mouse oocytes and ES cells, where they contribute to the repression of transposons. Endo-siRNAs have also been detected in germ cells of the adult testis (Song et al. 2011), but it is not known if this type of ncRNA is also involved in sex determination and early testis differentiation.

The third main class of small RNAs, piRNAs, are 24-31 nt long, derived from single-stranded piRNA precursor transcripts and processed in a Dicer-independent way (Vagin et al. 2006, Li et al. 2013). piRNAs associate with the PIWI subfamily of AGO proteins and are predominantly expressed in germ cells, where they are involved in transposon silencing through heterochromatin formation and RNA destabilization (Klattenhoff \& Theurkauf 2008, Weick \& Miska 2014). They play a major role in male development and fertility and will therefore be discussed in more detail below.

In addition to small ncRNAs, new techniques such as sequencing of whole transcriptomes have identified a large number of IncRNAs (Okazaki et al. 2002, Carninci et al. 2005, Consortium et al. 2007). LncRNAs vary in size from $200 \mathrm{bp}$ to several kilobase in size and are transcribed by RNA polymerase II. Similar to mRNAs they are often polyadenylated at the $3^{\prime}$ end and have a $5^{\prime}$ end cap structure. LncRNAs are transcribed from different regions within the genome. Many IncRNAs are transcribed from intergenic regions (Guttman et al. 2011, Ulitsky \& Bartel 2013), so-called long intergenic ncRNAs (lincRNAs), but there are also numerous IncRNAs transcribed from the sense or antisense strand of protein-coding genes (Wu et al. 2014). Some ncRNAs seem to be processed from 3'UTR of mRNAs (Mercer et al. 2011), whereas intronic IncRNAs are part of an intron from another transcript (Carninci et al. 2005, Consortium et al. 2007). Many of these IncRNAs were believed to be by-products from transcription, splicing, RNA processing, etc., but more and more data emerge demonstrating specific expression and function of various IncRNAs (for review, see Fatica \& Bozzoni (2014)). It appears that, similar to their heterogeneous origin, IncRNAs have a wide range of functions: they regulate chromatin remodelling by recruiting chromatin modifiers, control the transcriptional rate of genes and influence post-transcriptional processes such as inhibition or induction of translation (Mercer et al. 2009, Fatica \& Bozzoni 2014).

In this review, we will describe the cellular mechanisms underlying male sex determination and differentiation and the potential functions that ncRNAs have at each step of these processes. We will concentrate on mammalian male development with a specific focus on mice, but also discuss the role of ncRNAs in male sex differentiation in other species. Non-coding RNAs have been identified in all groups of animals, from vertebrates to flies and worms, and among ancient groups, such as cnidarians and sponges (Grimson et al. 2008). This indicates that ncRNAs as developmental regulators have a very ancient history and likely played a role very early in metazoan evolution. Both short and IncRNAs have been reported among diverse species. Among the former, small ncRNAs with silencing functions such as miRNAs, endogenous-siRNAs and piRNAs are all present in vertebrate as well as invertebrate cells, and all function to regulate gene expression, including post-transcriptional or translational silencing, and repression of retrotransposon activity (Malone \& Hannon 2009). While miRNAs tend to be structurally conserved, piRNAs and IncRNAs generally lack sequence conservation across species. In developing testes, all classes of ncRNAs have been reported in non-mammalian vertebrates, where their analysis is shedding light on their evolution and function. As in mammals, piRNAs are implicated in protecting the male germline from retroviral elements, and indeed are required for proper spermatogenesis in both mammals and non-mammals. In contrast, the exact role of microRNAs in testis determination is less well understood. The role for IncRNAs in the testis is even less clear, but studies in avian and fish cells point to chromatin modification to influence local gene expression (see below).

\section{The development of the bipotential genital ridge in mammals}

In mammals, testes and ovaries arise from paired indifferent and bipotential genital ridges, which develop from a thickening of the ventromedial surface of the mesonephros. In mice, the genital ridges are first visible at around 9.5 days post coitum (dpc) (Byskov 1986). Mutant and knockout analyses in mouse identified several key protein-coding genes that are responsible for the correct development of the bipotential ridge such as the nuclear receptor subfamily 5, group A, member 1 (Nr5a1, also known as steroidogenic factor 1 or Sf1), Wilms' tumour suppressor gene 1 (Wt1), empty spiracles homeobox 2 (Emx2), odd-skipped-related 1 (Odd1) and LIM homeobox gene 9 (Lhx9) (Luo et al. 1994, Sadovsky et al. 1995, Miyamoto et al. 1997, Schnabel et al. 2003, Wang et al. 2005). In contrast, ncRNAs have not been implicated in the formation of the indifferent genital ridge to date.

During the formation of the genital ridges, somatic cells coalesce with primordial germ cells (PGCs), the precursor of the gametes, which are specified extragonadally at the base of the allantois at around $6.5 \mathrm{dpc}$ in mouse (Ginsburg et al. 1990, Lawson \& Hage 1994). PGCs migrate from the allantois through the hindgut and the dorsal mesentery to colonize the developing genital 
ridges between 9.5 and 11.5 dpc (Clark \& Eddy 1975, Donovan et al. 1986). Master regulators of PGC specification include PR domain zinc finger protein 14, PRDM14 (Yamaji et al. 2008), PRDM1, also known as BLIMP1 (Ohinata et al. 2005, Vincent et al. 2005), and the RNA-binding protein LIN28 (West et al. 2009). Several groups have independently discovered that LIN28, and the related protein LIN28B, bind to the primary transcript of the let-7 miRNA and inhibits its processing into the mature miRNA (Heo et al. 2008, Rybak et al. 2008, Viswanathan et al. 2008). Let-7 is one of the first characterized miRNAs, which was identified in a study of developmental timing in $C$. elegans (Rougvie 2001). In mammals, the let-7 family has numerous members and has been shown to bind and repress Lin28 as well as Prdm1 (Nie et al. 2008, Viswanathan et al. 2008), connecting all three players during germ cell specification (Fig. 1).

\section{The differentiation of PGCs in mammals}

After entering the gonads, PGCs proliferate until $\sim 13.5 \mathrm{dpc}$, when they differentiate in a sex-specific manner. In an ovary, PGCs enter the first meiotic prophase, while in a testis they enter mitotic arrest (Bullejos \& Koopman 2004, Western et al. 2008). XX and $X Y$ germ cells were believed to not be sexually dimorphic until this differentiation process is initiated by their surrounding cells, testicular or ovarian somatic cells (Bowles \& Koopman 2010). This view has been challenged by two reports demonstrating sexually dimorphic gene expression in PGCs long before initiation of meiosis in an ovary and mitotic arrest in a testis. The first indication came from a study examining miRNAs expressed during early ES cell differentiation (Ciaudo et al. 2009). The authors showed that the miR302 family of microRNAs was highly expressed in XY, but not XX PGCs at 8.5 and $9.5 \mathrm{dpc}$, before PGCs arrive at the developing genital ridges (Ciaudo et al. 2009). However, it is unclear what regulates this male-enriched expression and what function these microRNAs have at this stage during development. In addition, a proteincoding gene, Lrrc34, as well as a IncRNA, AK015184, were detected in $\mathrm{XX}$ but not $\mathrm{XY}$ germ cells from $11.5 \mathrm{dpc}$, the time of sex determination and 2 days before the onset of sex-specific germ cell differentiation (Chen et al. 2012). Similar to the miRNAs, no function has been described for these genes in the PGCs to date.

In addition, several miRNAs have been shown to be expressed during and after PGC differentiation. The microRNA cluster miR-17-92 is highly expressed in XX and $X Y$ PGCs and this expression is reduced in female germ cells following entry into meiosis (Hayashi et al. 2008). miR-17-92 is one of the best-characterized oncogenic miRNA clusters (He et al. 2005), suggesting that these miRNAs are important for germ cell survival and proliferation. Similarly, another miRNA cluster known to promote proliferation, $\operatorname{miR}-290-295$, is also

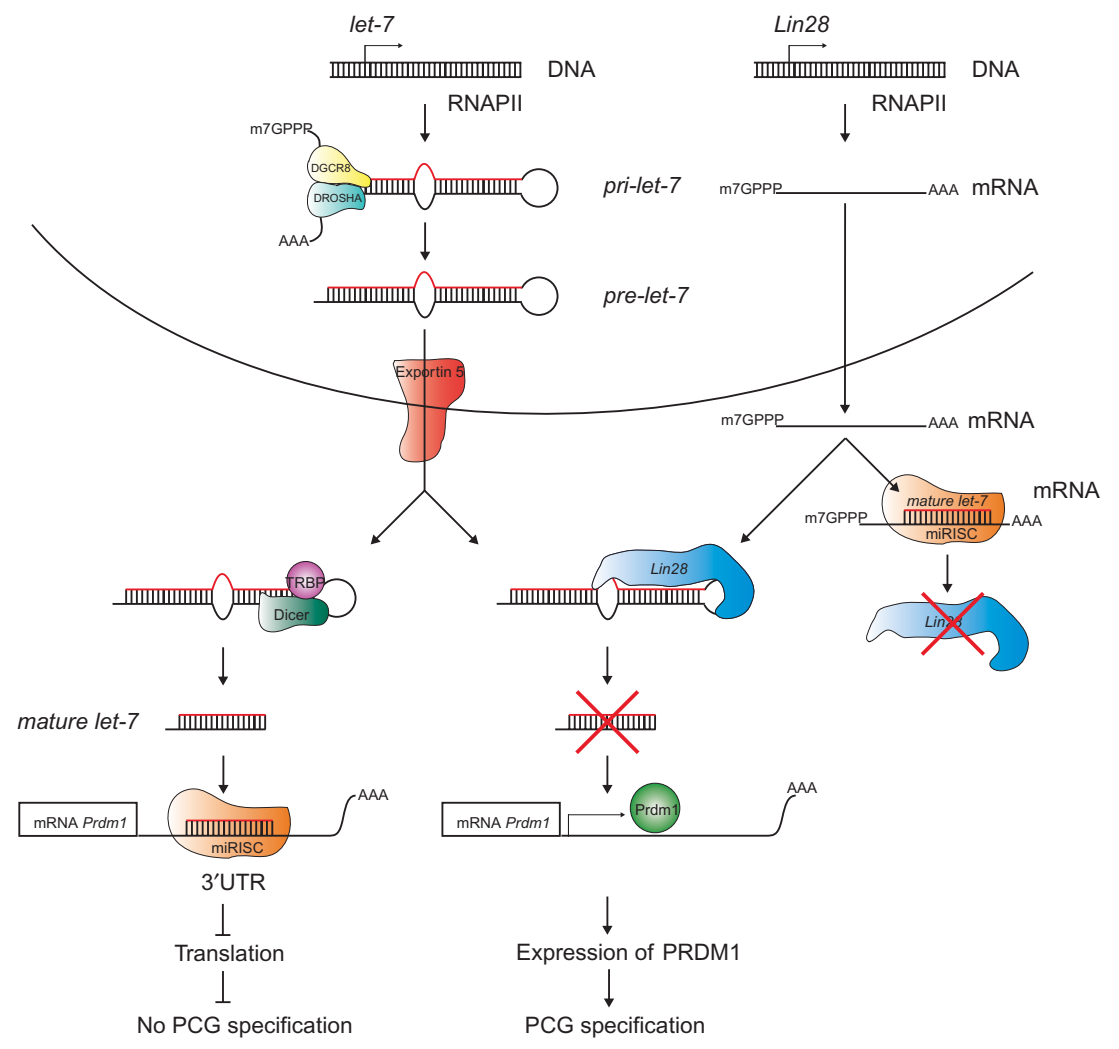

Figure 1 Cross-talk of LIN28, PRDM1 and the miRNA let-7 during PGC specification. In the absence of LIN28, the mature miRNA let-7 is generated through the canonical miRNA biogenesis pathway. Let-7 is transcribed by RNA polymerase II (RNAP II) into pri-let-7, which is cleaved by DROSHA and its cofactor DGCR8 to generate pre-let-7. Pre-let-7 is exported by Exportin 5 into the cytoplasm, where it is processed by Dicer and its partner RNA-binding protein TRBP. The guide strand of the mature let-7 duplex is loaded on the microRISC (miRISC), which then binds to the $3^{\prime} \mathrm{UTR}$ of Prdm1 and Lin28 mRNA leading to an inhibition of Prdm1 and Lin28 translation and thereby suppression of PGC specification. In turn, processing of let-7 is inhibited by the presence of LIN28. LIN28 binds pre-let-7 and prevents its processing by Dicer and TRBP into mature let-7. Reduced levels of mature let-7 result in the expression of Prdm1 and Lin28 and thereby PGC specification. 
highly expressed in PGCs (Hayashi et al. 2008). In contrast, the expression of other miRNAs, including $m i R$ $141,-200 a,-200 c$ and -323 , decreased during development (Hayashi et al. 2008), suggesting that they might inhibit differentiation. However, functional experiments need to be performed to elucidate their function during PGC development.

\section{$S R Y$ and sex determination in mammals}

In mammals, sex is determined genetically by the presence or absence of the male-determining factor SRY on the $\mathrm{Y}$ chromosome. Mouse Sry displays a very restricted expression pattern. It is only expressed for $\sim 2$ days during embryonic development and only in the developing genital ridge (Hacker et al. 1995). Its expression induces a cascade of gene expression and regulation that results in the formation of a testis. Expression of Sry is induced at $10.5 \mathrm{dpc}$ in the centre of the gonad, reaches its highest levels at $11.5 \mathrm{dpc}$ and disappears completely after $12.5 \mathrm{dpc}$ (Hacker et al. 1995, Bullejos \& Koopman 2001, Sekido et al. 2004, Wilhelm et al. 2005). Mutation analysis of a number of genes revealed insights into the regulation of Sry expression (for review see Svingen \& Koopman (2013)). Genes that have been implicated in the regulation of Sry expression include chromobox homolog 2 (Cbx2) (Katoh-Fukui etal. 2012), the +KST isoform of WT1 (Hammes et al. 2001), steroidogenic factor 1 (SF1), encoded by the gene Nr5a1 (Pilon et al. 2003), as well as the transcriptional co-factor CITED2 in combination with WT1 and SF1 (Buaas et al. 2009), GATA-binding protein 4 (Gata4) and its cofactor friend of GATA 2 (Fog2) (Tevosian et al. 2002), combined loss-of-function mutations in the insulin receptor genes, Ir and Igf1r (Nef et al. 2003, Pitetti et al. 2013), as well as mutations in the MAPK pathway, including Map3k4, its activator Gadd45 $\gamma$ and p38MAPKs (Bogani et al. 2009, Gierl et al. 2012, Warr et al. 2012).

Interestingly, in addition to its expression in the fetal testis, where Sry is both necessary and sufficient to induce male development, an unusual circular Sry transcript has been detected in adult mouse testis (Capel et al. 1993). It is likely that the splicing machinery generates this circular transcript due to the long inverted repeat surrounding the Sry locus. The function of this circular Sry transcript is unknown. Most likely it functions as a ncRNA, as it is not associated with polysomes (Capel et al. 1993). Interestingly, in the last couple of years, circular transcripts have been predicted to exist for thousands of genes. They are conserved between species and their expression is highly regulated (Salzman et al. 2012, Jeck et al. 2013, Memczak et al. 2013, Jeck \& Sharpless 2014), suggesting that these unusual transcripts indeed have a function. The best characterized function for a circular transcript is the one for the brain-enriched antisense transcript of cerebellar degeneration-related protein 1 (Cdr1as) transcript, also known as circular RNA sponge for miR-7 (ciRS-7). Circular Cdr1as exhibits 73 target sites for $m i R-7$, thereby functioning as a sponge, resulting in a decreased activity of $m i R-7$ and an upregulation of $m i R-7$ target genes (Kefas et al. 2008, Hansen et al. 2013a, b, Memczak et al. 2013). Importantly, the circular Sry transcript also possesses several putative target sites for a microRNA, miR-138, suggesting that, similar to circular Cdr1as, circSry could serve as sponge for miR-138 (Hansen et al. 2013a). Further investigations are necessary to clarify if circular transcripts play a role in the process of male sex determination and differentiation.

\section{Sex determination and testis development in non-mammalian vertebrates}

Interestingly, although the determination of sex is such a fundamental process, the molecular trigger is not widely conserved. Sry as the male-determining gene only exists in therian mammals (marsupials and eutherians). The search for alternative sex determination mechanisms has revealed a plethora of different ways depending on the species. Sex can be determined via purely genetic cues, such as in birds and mammals or, for example, through the temperature at which the eggs are incubating, as in many reptiles (Matson \& Zarkower 2012, Eggers et al. 2014). In contrast to mammals that have a $X X$ female: $X Y$ male sex chromosome system, birds have a ZZ male: ZW female system. In addition, the sex chromosomes of birds are not homologous to those of mammals but have evolved from a different autosomal chromosome pair (Marshall Graves 2008). It is therefore not surprising that birds lack the mammalian Sry gene. Instead, sex is likely dependent on Z-chromosome dosage, i.e., two doses in males, ZZ, and one dose in females, ZW (Chue \& Smith 2011). The best $Z$-linked candidate gene under this hypothesis is doublesex and mab3 related transcription factor $1(D M R T 1)$, a conserved gene that encodes a zinc finger-like transcription factor. Dmrt genes play a prominent role in vertebrate sex determination and gonadal development. In therian mammals, Dmrt1 is expressed in developing $X Y$ gonads after Sry and is required only postnatally for proper somatic and germ cell development (Raymond et al. 2000). However, in other vertebrates, Dmrt genes can have a more central role. In birds, DMRT1 is expressed in the embryonic gonads, where it is more highly expressed in testes, and knockdown using RNA interference feminises male (ZZ) gonads (Smith et al. 1999, 2009). Similarly, a duplicated copy of autosomal dmrt1, called dmrt1bY/dmy, is the master switch for testis determination in fish species such as medaka (Oryzias latipes) (Matsuda et al. 2002), and in the amphibian Xenopus laevis a divergent Dmrt gene on the female $W$ sex chromosome $(d m w)$ antagonises autosomal dmrt1 to have ovary-determining function (Yoshimoto et al. 2008). Among reptiles with 
temperature-sensitive sex determination, Dmrt1 is upregulated at the male- but not the female-inducing temperature at the time of gonadal sex differentiation (Shoemaker et al. 2007a, b). Taken together, these observations point to a key role for Dmrt genes in vertebrate sex determination. Nevertheless, the control of sex-determining pathways appears to be remarkably labile especially in lower vertebrates, where different genes have been co-opted to act as master testis determinants (Cutting et al. 2013). For example, amhy, a duplicated copy of the anti-Müllerian hormone (AMH) is the master testis determinant in one fish species, the Patagonian pejerrey (Odontesthes hatcheri) (Hattori et al. 2012), whereas in the rainbow trout, an immunerelated gene, $s d Y$, is the master testis determinant (Yano et al. 2012).

Following sex determination, other elements of the pathway tend to be conserved between mammals and non-mammals. These include SOX9, a highly conserved HMG domain transcription factor that is implicated in testis development across all groups from fish to reptiles, birds and mammals (Morais da Silva et al. 1996, Western et al. 1999). In female embryos of egg-laying species such as birds and reptiles, estrogen is required for proper ovary formation, and testis-enriched DMRT1 can antagonise estrogen production (Elbrecht \& Smith 1992, Yao et al. 2004, Lambeth et al. 2014). In general, studies of non-mammalian species have found that gonadal sex differentiation into ovaries or testes is morphologically conserved among vertebrates, involving the same cell types and many of the same protein coding genes. As noted above, molecular divergence lies primarily at the top of the sex-determining cascades.

\section{Regulation of Sox9 expression by protein-coding and ncRNAs}

In mammals, Sry is expressed in pre-Sertoli cells, the supporting cells in the testis, which are also the organizers for all other testis-specific cell types. In the short period of Sry expression, its key role is the upregulation of Sox9, which encodes a transcription factor belonging to the same SRY-like HMG domain family (Bowles et al. 2000). Before Sry expression is upregulated in the $\mathrm{XY}$ genital ridge, Sox9 is expressed at low levels in both the developing testis and the ovary (Kobayashi et al. 2005) due to the binding and activation by SF1 to the testis enhancer sequence (TES) $14 \mathrm{~kb}$ upstream of the Sox9 transcription start site (Sekido \& Lovell-Badge 2008). Subsequently, SRY binds together with SF1 to a $1.4 \mathrm{~kb}$ core element (TESCO) located within TES resulting in the upregulation of Sox 9 transcription in the testis, whereas Sox9 expression becomes undetectable in the ovary. Once Sox9 is expressed at a high enough level, SOX9 itself binds along with SF1 to TESCO to maintain its own expression (Sekido \& Lovell-Badge 2008). In addition, two positive feedback loops are described for the maintenance of Sox9 expression: first, SOX9 upregulates directly or indirectly FGF9, which then activates FGF signalling via FGF receptor 2 (FGFR2), resulting in Sox9 upregulation (Kim et al. 2007, Bagheri-Fam et al. 2008). Secondly, SOX9 directly stimulates the expression of the prostaglandin D synthase (Ptgds) gene, which in turn produces prostaglandin $\mathrm{D}_{2}$ $\left(\mathrm{PGD}_{2}\right)$, leading to the translocation of SOX9 protein from the cytoplasm into the nucleus and the upregulation of its expression (Malki et al. 2005, Wilhelm et al. 2005, Wilhelm et al. 2007, Moniot et al. 2009).

While TESCO also has been located in the human genome $\sim 13 \mathrm{~kb}$ upstream of the SOX9 transcription start site (Sekido \& Lovell-Badge 2008), it is not known if TESCO also mediates testis-specific expression of SOX9 in humans. Mapping of copy number variations in human patients with 46,XX male and 46,XY female development identified a long distance regulatory region upstream of SOX9, called RevSex, that is likely to harbour an enhancer driving testis-specific expression (Benko et al. 2011). Interestingly, this region encodes two IncRNAs, TCONS_00025195 and TCONS_00025196 (Smyk et al. 2013), which might be involved in the regulation of SOX9 expression in human testes (Fig. 2).

While the upregulation of Sox9 expression in the XY genital ridge has been studied in detail, not much is known about what causes its downregulation in the developing ovary. Recently, a microRNA, miR-124, has been implicated in the inhibition of Sox9 expression in the ovary (Fig. 2). This miRNA has been shown to regulate Sox9 expression in the brain (Cheng et al. 2009). miR-124 was identified in a microarray screen of embryonic mouse gonads as being upregulated in the developing ovary and downregulated in the testis (Real et al. 2013), suggesting a role during ovarian differentiation. However, this ovary-enriched expression was not detected by a high-throughput sequencing approach (Rakoczy et al. 2013). Nevertheless, inhibition of miR124 in XX gonadal cells using antagomirs (small, antisense molecules that bind and inhibit miRNAs) resulted in an upregulation of Sox9 expression, indicating that miR-124 is necessary for the repression of Sox9 in the developing ovary (Real et al. 2013). In contrast, overexpression of $m i R-124$ in XY gonadal cells was not sufficient to repress Sox9 expression at the mRNA and protein level (Real et al. 2013). These knockdown and over-expression analyses were performed in isolated primary cells, and it remains to be tested if this miRNA has an in vivo function. Knockout of miR-124a-1 and miR-124a-3 in mice does not result in female-to-male sex reversal (Sanuki et al. 2011, Park et al. 2012), as would be expected if these miRNAs were necessary for the repression of Sox9 in the ovary. However, all three miR-124 genes have been reported to be expressed in the developing ovary (Real et al. 2013), which could mask any phenotype in single knockout mice, and a triple knockout mouse would be required to draw definite 


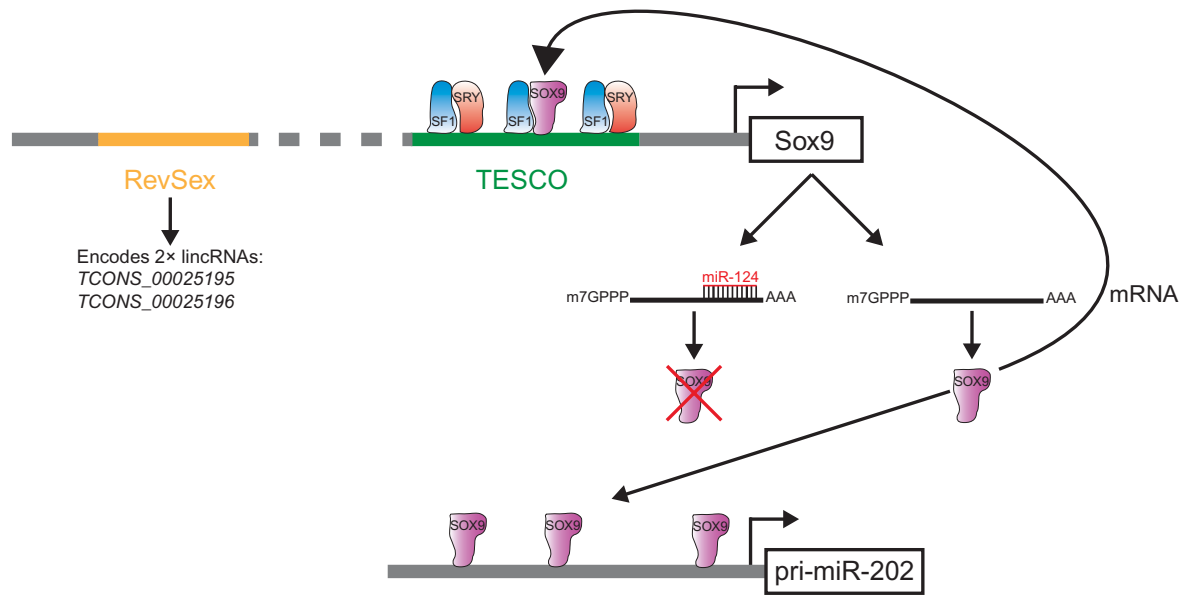

Figure 2 Putative regulation of Sox 9 expression by ncRNAs. In mice, Sox 9 transcription is upregulated by the binding of SF1 and SRY or SF1 and SOX9 to the enhancer region TESCO, which is located $13 \mathrm{~kb}$ upstream of the Sox 9 transcription start site. The TESCO sequence is also present in humans, but its relevance for testis-specific Sox9 expression is not clear. Rather, the analyses of human patients with 46,XX and 46,XY DSD identified a second control region, called RevSex, located upstream of the SOX9 transcription start site. This region harbours two lincRNAs, TCON_00025195 and TCON_00025196, which might be involved in regulating SOX9 expression. In addition, Sox9 expression can be regulated by miR-124 by binding to the 3'UTR of Sox9 mRNA, however it is unclear if this regulation occurs during gonad differentiation. Finally, SOX9 likely functions as a transcriptional activator of miRNAs such as $m i R-202$ and $m i R-140$.

conclusions. Also, the ovary-enriched expression of miR-124 was shown at $13.5 \mathrm{dpc}$, whereas its expression level at $11.5 \mathrm{dpc}$, the stage at which Sox9 expression is downregulated in the ovary (Kobayashi et al. 2005), was very low and indistinguishable from the expression level in the XY genital ridge (Real et al. 2013), suggesting that miR-124 might not responsible for the initial downregulation of Sox9 in the ovary, but may be involved in the maintenance of Sox9 repression.

\section{Regulation of miRNA expression by SOX9 during mammalian Sertoli cell differentiation}

The expression of SOX9 results in the differentiation of Sertoli cells (Sekido et al. 2004, Wilhelm et al. 2005), which can be considered as the organizing centres of the developing testis. They drive the differentiation of other cell types by the expression and secretion of essential factors, many of which are directly upregulated by SOX9 or have been at least suggested to be transcriptionally regulated by SOX9 (see below and for review see Svingen \& Koopman (2013)). Overall, it induces global cellular and morphological changes, including the migration of endothelial cells from the mesonephros to form the testis-specific vasculature, an increase in proliferation and the formation of testis cords, which comprise clusters of PGCs surrounded by Sertoli cells (Martineau et al. 1997, Capel et al. 1999, Schmahl et al. 2000, Schmahl \& Capel 2003, Cool et al. 2008, Combes et al. 2009), resulting in the formation of a testis.

SOX9 has also been implicated in the transcriptional regulation of miRNAs. We have shown recently that the expression of pri-miR-202 is downstream of SOX9 in the developing mouse testis (Wainwright et al. 2013). Both strands, miR-202-3p and miR-202-5p, were initially identified in the embryonic gonad by using highthroughput sequencing of small RNAs from differentiating XY and XX gonads (Rakoczy et al. 2013). The sequence of miR-202 is conserved among vertebrates and both strands, miR-202-5p and $-3 p$, are upregulated during testis development not only in mouse but also in chicken embryos. In both species, they are expressed in the key Sertoli cell lineage. In chickens, experimental male-to-female sex reversal with oestrogen causes a decline in chicken miR-202-3p expression (Bannister et al. 2011). Interestingly, miR-202-3p also was found to be one of the main miRNAs depleted in the sterile gonads of Xenopus hybrids, suggesting it is important for gametogenesis (Michalak \& Malone 2008). To investigate the function of pri-miR-202 in mouse embryonic gonads in vivo, a mouse model was generated in which pri-miR-202 is over-expressed in somatic cells of the developing testis and ovary using the regulatory region of the Wt1 (Wainwright et al. 2013). Ectopic expression of pri-miR-202 in XX gonads did not result in any molecular changes to the ovarian differentiation pathway, showing that miR-202 is not sufficient to switch on testis development (Wainwright et al. 2013). However, this does not exclude a possible function during testis differentiation, which would require the generation of a miR-202-null mouse model.

\section{Mechanisms involved in the differentiation of Leydig cells and peritubular myoid cells in mammals}

One of the factors expressed and secreted by Sertoli cells is desert hedgehog $(\mathrm{DHH})$, which is responsible for the differentiation of fetal Leydig cells and acts through its 
receptor patched 1, PTCH1, expressed on all interstitial cells (Bitgood et al. 1996, Clark et al. 2000, Yao et al. 2002). Interestingly, DHH is not only necessary but also sufficient for Leydig cell differentiation. Ectopic activation of the Hedgehog pathway in an ovary is enough to induce Leydig cells differentiation (Barsoum et al. 2009). However, DHH is not the only factor important for Leydig cell differentiation. Activation of Notch signalling reduces and inhibition of Notch signalling increases the number of Leydig cells in the developing testis (Tang et al. 2008), demonstrating that also this signalling pathway controls the differentiation of these cells. Similarly, the miRNA miR-140, expressed in Sertoli cells and shown to be directly upregulated by SOX9 (Nakamura et al. 2011, Yang et al. 2011), influences Leydig cell differentiation. Loss of miR-140 results in an increase in Leydig cell numbers (Rakoczy et al. 2013). However, it is not known which genes are regulated by miR-140 within Sertoli cells that indirectly influence Leydig cell differentiation, although predicted target genes have been shown to play a role in testis development and Leydig cell differentiation and function (Rakoczy et al. 2013).

$\mathrm{DHH}$ produced by Sertoli cells not only controls the differentiation of Leydig cells, but also another testisspecific cell type, so-called peritubular myoid cells; long, flattened cells that surround Sertoli cells at the testis cords and secret, together with Sertoli cells, extracellular matrix proteins, which form a basal lamina between the two cell types (Tung et al. 1984). Peritubular myoid cells become contractile at later stages to pump the sperm into the epididymis. To date, no factors, other than $\mathrm{DHH}$, have been implicated in the differentiation of peritubular myoid cells, including ncRNAs.

\section{The differentiation of the male reproductive tract in mammals}

Steroidogenic Leydig cells are localized in the interstitium of $X Y$ gonads and induce, through androgen production, the development of secondary male sexual characteristics such as the differentiation of the Wolffian duct into the male reproductive tract including epididymis, vas deferens and seminal vesicles (Eik-Nes 1969, O'Shaughnessy et al. 2007). In addition, SOX9 in Sertoli cells upregulates the expression of $\mathrm{AMH}$ (Arango et al. 2008), which causes the degradation of the Müllerian ducts, which otherwise would differentiate into the female reproductive tract, including oviduct, uterus and upper vagina. While there are good indications that ncRNAs, especially miRNAs, play a role in the female reproductive tract (Hong et al. 2008, Nagaraja et al. 2008, Gonzalez \& Behringer 2009), very little is known about the role of ncRNA in male reproductive tract development. Small ncRNAs, including miRNAs and piRNAs, have been identified in the human epididymis (Zhang et al. 2010, Li et al. 2012), but their function and whether they are necessary for epididymal differentiation is unknown.

\section{The role of piRNAs in testis development}

As mentioned above, piRNAs are predominantly expressed in germ cells and are associated with the PIWI subfamily of AGO proteins. PIWI-interacting RNAs have been identified in both vertebrate and invertebrates, indicating that, as a class, they have a very ancient history within animal cells (Ruby et al. 2006, Vagin et al. 2006, Houwing et al. 2007). PIWI is named for 'P-element induced wimpy testis' and was first identified by an enhancer trap based screen in 1997 in Drosophila (Lin \& Spradling 1997). Analysis of Piwi mutants revealed that PIWI proteins are required for the maintenance and renewal of germline stem cells and the inhibition of retrotransposons mobilization in the male germline (Lin \& Spradling 1997, Cox et al. 1998, Kalmykova et al. 2005). However, increasing evidence also points to a role in the female germline and folliculogenesis (Lim et al. 2013).

In mice, 3 Piwi genes exist, Piwil1 (Miwi), Piwil2 (Mili), and Piwil4 (Miwi2), which are all essential for spermatogenesis, as null mutation of each resulted in male sterility (Deng \& Lin 2002, Kuramochi-Miyagawa et al. 2004, Carmell et al. 2007). PIWIL2 expression starts at $12.5 \mathrm{dpc}$ and persists into adulthood, whereas PIWIL4 is expressed from $15.5 \mathrm{dpc}$ to 3 days postnatally and PIWIL1 in adult testes from 14 days postnatally (Aravin \& Hannon 2008). The different PIWI proteins also recognize and bind different piRNAs, with 26- to 27-nt-long piRNAs binding to PIWIL2, 28- to 29-nt piRNAs to PIWIL4 and the majority of piRNAs binding to PIWIL1 at 30 nt (Aravin et al. 2006, Girard et al. 2006, Aravin \& Hannon 2008). Recent data show that the PIWI/piRNA protein machinery is conserved in various vertebrate lineages, where it plays a conserved role in disabling transposons and protecting germ cells (Lim et al. 2013). Table 1 shows the phylogenetic distribution of PIWI homologues and functionally related proteins Maelstrom, VASA and TDRD1 - amongst vertebrates and Drosophila. Similar to mammals, in zebrafish (Danio rerio) the piwi homologues, ziwi and zili, are expressed in embryonic germ cells, where mutagenesis studies show that they are required for germ cell maintenance and transposon silencing (Houwing et al. 2007). This is likely to be a feature of piRNAs across the developing gonads of all vertebrate embryos. In adult amniotes, such as mice, platypuses (a monotreme mammal) and chickens, PIWI pathway proteins are all expressed in both testis and ovary (Murchison et al. 2008, Lim et al. 2013), although targeted deletion of PIWIs in mice suggest a requirement for spermatogenesis but not oogenesis (Deng \& Lin 2002). In chickens, PIWI homologues have been identified that are called CIWI and CILI (Kim et al. 2012). At the amino acid level, CIWI 
Table 1 piRNA pathway genes amongst vertebrates (reproduced from Lim SL, Tsend-Ayush E, Kortschak RD, Jacob R, Ricciardelli C, Oehler MK, Grutzner F 2013 Conservation and expression of PIWI-interacting RNA pathway genes in male and female adult gonad of amniotes. Biology of Reproduction 89 136., with permission).

\begin{tabular}{|c|c|c|c|c|c|c|c|c|}
\hline Species & Piwi/Aub/Ago3 & Piwil1 & Piwil2 & Piwil3 & Piwil4 & Mael & Vasa & Tdrd1 \\
\hline Drosophila & + & & & & & + & + & + \\
\hline Human & & + & + & + & + & + & + & + \\
\hline Mouse & & + & + & - & + & + & + & + \\
\hline Opossum & & + & + & - & + & + & + & + \\
\hline Platypus & & + & + & - & + & + & + & + \\
\hline Chicken & & + & + & - & - & + & + & + \\
\hline Zebrafinch & & + & + & - & - & + & + & + \\
\hline Xenopus & & + & + & - & + & + & + & - \\
\hline Lizard & & + & + & - & + & + & + & + \\
\hline Zebrafish & & + & + & - & - & + & + & + \\
\hline
\end{tabular}

shows 78,76 and $64 \%$ similarity with human, mouse and zebrafish PIWIs respectively, with especially highly conserved PAZ and PIWI domains (80\%). RNAi-induced knockdown of CIWI and CILI results in upregulated expression of the repetitive element $C R 1$ and an increase in DNA double-strand breakage in isolated chicken PGCs (Rengaraj et al. 2014). These data indicate that, similar to zebrafish and mice, the PIWI/piRNA pathway is operational in avian gametes. Thus, the piRNA machinery is conserved in structure and function. In addition to slicing and therefore RNA degradation, PIWI proteins were also involved in transposon silencing by CpG DNA methylation in PGCs (Kuramochi-Miyagawa et al. 2004, Carmell et al. 2007). Recent data suggest additional functions, including transcriptional regulation, mRNA deadenylation and transgenerational effects (Weick \& Miska 2014).

Similar to the differential expression of the PIWI proteins, piRNA expression appears to be highly regulated and occurs in two waves, namely prepachytene and pachytene piRNAs (Aravin et al. 2007a). In mice, the expression of pre-pachytene piRNAs starts at around $12.5 \mathrm{dpc}$ in PGCs (KuramochiMiyagawa et al. 2004, Aravin et al. 2007a, Aravin \& Hannon 2008). These piRNAs bind to PIWIL2 and PIWIL4 and are involved in transposon defence (Aravin et al. 2007b, Carmell et al. 2007). The second pool of piRNAs is expressed at the pachytene stage of meiosis until the sperm reaches the haploid elongated spermatid stage during spermatogenesis, and are associated with PIWIL1 and PIWIL2 proteins. This burst of piRNA expression in the testis is required for the completion of spermatogenesis (Deng \& Lin 2002). Their function appears to be independent of transposon suppression, but is conserved in adult chicken testis. The transcription factor, A-MYB, activates both pachytene piRNA precursors and piRNA biogenesis factors, and is active in adult mouse and chicken testes, pointing to a conserved mechanism of pachytene-enriched piRNAs required for proper spermatogenesis ( $\mathrm{Li}$ et al. 2013). However, in contrast to their function, piRNA sequences themselves have evolved rapidly, with generally poor conservation, even among closely related species.
Whereas the biogenesis of miRNAs and siRNAs requires the catalytic activity of Dicer, the generation of piRNAs is Dicer independent (Aravin et al. 2006, Vagin et al. 2006, Watanabe et al. 2006, Houwing et al. 2007). Biogenesis of primary piRNAs begins with the transcription of long, single-stranded piRNA precursor transcripts (Aravin et al. 2006, Watanabe et al. 2006), which are exported from the nucleus and cleaved into primary antisense piRNAs. In addition, a secondary biosynthesis mechanism exists, the so-called ping-pong mechanism, which results in the amplification of piRNAs (Brennecke et al. 2007). Here, the antisense piRNA derived from the primary pathway is loaded onto PIWIL2 in mammals and the protein-RNA complex binds and slices transposon RNA, resulting in the degradation of the transposon RNA and the generation of sense piRNAs. Sense piRNAs in turn associate with PIWIL4 to bind and cleave the antisense transcript derived from piRNA clusters to amplify the number of antisense piRNA (Aravin et al. 2007 b, Brennecke et al. 2007). In addition, other piRNAs are derived from the $3^{\prime} U T R$ s of proteincoding genes, which has been shown to be conserved from Xenopus to mammals (Robine et al. 2009, Ha et al. 2014). Using shotgun cloning or high-throughput nextgeneration sequencing, piRNAs have been identified in embryonic and adult chicken testis (Zhang et al. 2013, Rengaraj et al. 2014). Despite some challenges associated with the low sequence conservation of small ncRNAs, chicken piRNAs have been annotated and mapped in clusters across the chicken genome. They can be derived from either repetitive elements or exons (Yang et al. 2012).

\section{The role of piRNAs in sex determination}

Is there a role for piRNAs in regulating sex determination during embryogenesis? It is unlikely that this is the case in mammals, as piRNA expression is predominantly germ cell-specific (Girard et al. 2006, Grivna et al. 2006, Lau et al. 2006, Watanabe et al. 2006) and PIWI proteins as well as piRNAs are essential for germ cell proliferation, maintenance and/or differentiation and therefore fertility (e.g., Deng \& Lin 2002, Carmell et al. 2007, 
Kuramochi-Miyagawa et al. 2010), but not sex determination.

In contrast, evidence from invertebrates points to a key role at least in one species. Among flies, moths and other insects, sex is determined cell-autonomously throughout the body of the entire embryo. The silkworm Bombyx mori uses a ZW female: ZZ male sex chromosome system, with the $W$ sex chromosome known to be female-determining. The female $W$ chromosome is enriched in piRNAs, and one of these, dubbed Feminiser $($ Fem), acts as the primary female-sex determining gene (Kawaoka et al. 2011, Kiuchi et al. 2014). The Fem sequence is reiterated on the silkworm $\mathrm{W}$ sex chromosomes, and encodes a mature piRNA that is expressed in embryos and acts to regulate the Doublesex gene. Doublesex is a major sex-determining gene among insects. The primary transcript is spliced in a sexually dimorphic fashion, leading to two different proteins, with female- and male-specific functions respectively. These isoforms regulate downstream targets that coordinate female vs male development throughout the body and not just in the gonads. When Fem is experimentally inhibited, Doublesex is spliced in the male mode, leading to male development. In normal female gonads, the Fem piRNA acts to cleave a Z-chromosome linked transcript, Masc, that otherwise produces a zinc finger protein that directs the male-specific splicing of Doublesex (reviewed in Whitworth \& Oliver (2014)). The vertebrate homologue of Doublesex is DMRT1, a highly conserved zinc finger-like transcription factor with a pervasive role in testicular morphogenesis (Gamble \& Zarkower 2012, Matson \& Zarkower 2012). Although differential splicing of DMRT1 has been reported among vertebrates (Huang et al. 2005), there is currently no evidence to suggest that vertebrate DMRT1 might be regulated by a piRNA. However, this has not been thoroughly investigated.

\section{The role of IncRNAs in dosage compensation}

In species with genetic sex determination, such as the $X X$ female: $X Y$ male system in mammals and the ZW female: ZZ male system in birds, males and females have a difference in sex chromosome-linked gene dosage, which has resulted in the evolution of dosage compensation mechanisms. In mammals, this is realized by the inactivation of one of the $X$ chromosomes through coating by a IncRNA called Xist ( $X$ inactive specific transcript). The 19-kilobases-long transcript $X i s t$ is only transcribed from the inactive $X$ chromosome and coats the $\mathrm{X}$ chromosome in cis, repressing the expression of hundreds of genes. Prior to inactivation, a IncRNA that is antisense to Xist, called Tsix, is expressed. Upon differentiation, the expression Tsix is downregulated from one of the $\mathrm{X}$ chromosomes, resulting in the Xist and inactivation of this $X$ chromosome. On the active $X$, the maintained expression of Tsix prevents full-length Xist expression and X-linked gene expression is unaffected (reviewed in Moran et al. (2012)) This phenomenon of dosage compensation in mammals is clearly regulated by IncRNAs. In other groups, such as birds, there is no chromosome-wide inactivation of one sex chromosome in the homogametic sex. However, there is potential involvement of IncRNAs in dosage compensation in chickens as well. Chickens and other birds have a ZZ male: ZW female sex chromosome system. As noted above, the Z-linked transcription factor gene, DMRT1, is thought to play a central role in avian sex determination by directing testis development in ZZ embryos. Overexpression of DMRT1 induces the male-specific genes, HEMGN, SOX9 and AMH (Lambeth et al. 2014) (Fig. 3). Meanwhile, knockdown of DMRT1 expression with RNAi results in feminization of the gonads, and an upregulation of both FOXL2 and Aromatase, which are female marker genes (Smith et al. 2009). MHM is a $2.2 \mathrm{~kb}$ reiterated sequence located on the chicken $Z$ sex chromosome, but apparently absent in most other birds. It is only transcribed in female cells, where it produces a 9-kb-IncRNA that accumulates in the nucleus near its site of transcription, quite close to the DMRT1 locus (Teranishi et al. 2001). Although there is no chromosome wide $Z$ inactivation mechanism in birds to equalise $Z$ dosage, $M H M$ is located within a region of the $Z$ shows a higher degree of equalized $Z$ expression than elsewhere, and corresponds with hyperacetylation of histone $\mathrm{H} 4$, which is associated with increased gene expression (Bisoni et al. 2005, Melamed \& Arnold 2007). It has therefore been suggested that it may regulate local dosage compensation, perhaps by upregulating nearby genes and hence hyperacetylation of histone 4 in ZW female cells.

However, another hypothesis is that MHM may play a role in chicken gonadal sex differentiation (Fig. 3). In male cells (ZZ), MHM is hypermethylated and transcriptionally silent, whereas in female cells (ZW), it is hypomethylated and transcribed. Given its close proximity to $D M R T 1$, it has been suggested that $M H M$ may influence or dampen expression of DMRT1 in female cells, as these DMRT1 levels are always lower than in males. This could occur through MHM IncRNA coating the chromosome adjacent to the DMRT1 locus, inducing local chromatin conformational changes that may interfere with transcription factor binding. Indeed, mis-expression of $M H M$ in early ZZ chicken embryos appears to disrupt DMRT1 expression (Roeszler et al. 2012), while injection of $M H M$ expression plasmids into adult chicken testes quenches DMRT1 expression. Further analysis of $M H M$ will involve knockdown or knockout in vivo. In addition, MHM likely has other roles beyond gonadal sex differentiation, as it is widely expressed in female embryos. The absence of $M H M$ in most other birds may reflect the poor conservation of IncRNAs in general. Since IncRNAs are implicated mainly in chromatin confirmation, they may have 


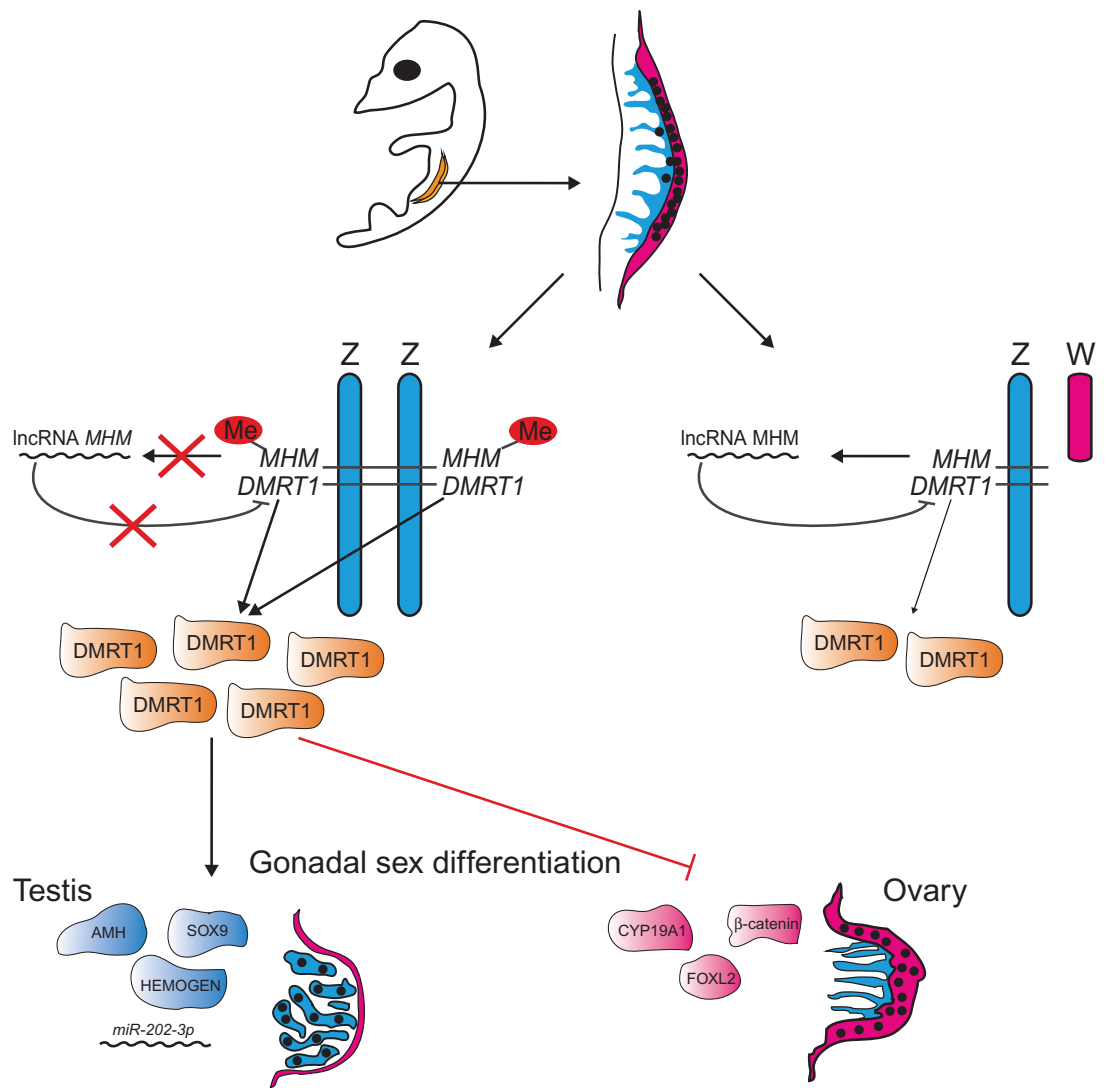

Figure 3 Potential roles of the long non-coding RNAs MHM in chicken. In ZZ male gonadal cells, Z-linked $M H M$, a long non-coding RNA, is methylated and transcriptionally silent. The neighbouring DMRT1 gene is transcribed, and is required for testis development, activating genes such as HEMOGEN and SOX9. MiRNA-202-3p is also expressed in testis and may play a role is cord organisation. In ZW female cells, MHM is hypomethylated and transcribed into long-noncoding RNA that coast the $Z$ adjacent to the $D M R T 1$ locus. It may quench DMRT1 expression, leading to less DMRT1 protein and allowing ovarian pathway genes to become active (e.g., FOXL2, CYP19A1 and $\beta$-catenin). fewer sequence constraints than, for example, microRNAs. Other sequences could perform analogous roles, even if not structurally homologous.

\section{Conclusions and future directions}

In recent years, substantial progress has been made in understanding the role of some ncRNAs, such as piRNAs, in male sex determination and differentiation, while the investigation of other ncRNAs has just begun. The expression of miRNAs in embryonic gonads at the time of sex determination and also at later stages during testis differentiation and in the postnatal testis has been studied extensively in different species. Surprisingly, depending on the experimental setup, there is little overlap between the different studies with respect to the miRNAs that were detected (e.g., Papaioannou et al. 2009, Aguilar et al. 2010, Rakoczy et al. 2013). In addition, deletion of Dicer or Drosha demonstrated only a relatively late role for miRNAs in the postnatal testis (Hayashi et al. 2008, Maatouk et al. 2008, Papaioannou et al. 2009, Huang \& Yao 2010), suggesting that miRNAs might not play a role during the early stages of sex differentiation. However, miRNAs appear to be very stable, at least in the testis, resulting in a loss of all miRNAs only after several days following Dicer deletion (Papaioannou et al. 2009). Hence, the deletion of Dicer or Drosha in the developing testis is not a useful strategy to investigate the function of miRNAs at these early steps of sex determination and differentiation. In contrast, specific miRNAs that have been shown to be expressed at these stages need to be examined individually. From the few examples tested to date, it appears that, similar to other systems, miRNAs might only play a modulatory role during sex determination, and loss-of-function or gain-of-function analysis causes only a relatively mild phenotype.

The class of ncRNAs about which we possibly know the least as far as its role during male sex differentiation are IncRNAs. Similar to miRNAs, these RNAs have been shown to be expressed (Chen et al. 2012), but functional analysis is lacking. However, recent technical advances, especially genome editing tools such as the TALEN and CRISPR/CAS9 systems, offer the exciting opportunity to perform in vivo loss-of-function analysis for specific ncRNAs, including miRNAs and IncRNAs, that is feasible considering both the cost and time involved and is not restricted to species such as mice, fish and Drosophila. These functional analyses will not only provide a more complete picture of the evolution and the molecular mechanisms driving male sex differentiation, but will also provide new candidate genes likely to be causative for disorders of sex development and male infertility in humans. 


\section{Declaration of interest}

The authors declare that there is no conflict of interest that could be perceived as prejudicing the impartiality of the review.

\section{Funding}

This work was supported by Future Fellowships to C A Smith (FT100100750) and D Wilhelm (FT110100327) by the Australian Research Council.

\section{References}

Aguilar AL, Piskol R, Beitzinger M, Zhu JY, Kruspe D, Aszodi A, Moser M, Englert C \& Meister G 2010 The small RNA expression profile of the developing murine urinary and reproductive systems. FEBS Letters $\mathbf{5 8 4}$ 4426-4434. (doi:10.1016/j.febslet.2010.09.050)

Arango NA, Kobayashi A, Wang Y, Jamin SP, Lee HH, Orvis GD \& Behringer RR 2008 A mesenchymal perspective of Mullerian duct differentiation and regression in Amhr2-lacZ mice. Molecular Reproduction and Development 75 1154-1162. (doi:10.1002/mrd.20858)

Aravin AA \& Hannon GJ 2008 Small RNA silencing pathways in germ and stem cells. Cold Spring Harbor Symposia on Quantitative Biology 73 283-290. (doi:10.1101/sqb.2008.73.058)

Aravin A, Gaidatzis D, Pfeffer S, Lagos-Quintana M, Landgraf P, lovino N, Morris P, Brownstein MJ, Kuramochi-Miyagawa S, Nakano T et al. 2006 A novel class of small RNAs bind to MILI protein in mouse testes. Nature 442 203-207.

Aravin AA, Sachidanandam R, Girard A, Fejes-Toth K \& Hannon GJ 2007 a Developmentally regulated piRNA clusters implicate MILI in transposon control. Science 316 744-747. (doi:10.1126/science.1142612)

Aravin AA, Hannon GJ \& Brennecke J 2007b The Piwi-piRNA pathway provides an adaptive defense in the transposon arms race. Science $\mathbf{3 1 8}$ 761-764. (doi:10.1126/science.1146484)

Bagheri-Fam S, Sim H, Bernard P, Jayakody I, Taketo MM, Scherer G \& Harley VR 2008 Loss of Fgfr2 leads to partial XY sex reversal. Developmental Biology 314 71-83. (doi:10.1016/j.ydbio.2007.11.010)

Bannister SC, Smith CA, Roeszler KN, Doran TJ, Sinclair AH \& Tizard ML 2011 Manipulation of estrogen synthesis alters MIR202* expression in embryonic chicken gonads. Biology of Reproduction 85 22-30. (doi:10.1095/biolreprod.110.088476)

Barsoum IB, Bingham NC, Parker KL, Jorgensen JS \& Yao HH 2009 Activation of the Hedgehog pathway in the mouse fetal ovary leads to ectopic appearance of fetal Leydig cells and female pseudohermaphroditism. Developmental Biology 329 96-103. (doi:10.1016/j.ydbio.2009. 02.025)

Benko S, Gordon CT, Mallet D, Sreenivasan R, Thauvin-Robinet C, Brendehaug A, Thomas S, Bruland $\mathrm{O}$, David $\mathrm{M}$, Nicolino $\mathrm{M}$ et al. 2011 Disruption of a long distance regulatory region upstream of SOX9 in isolated disorders of sex development. Journal of Medical Genetics 48 825-830. (doi:10.1136/jmedgenet-2011-100255)

Bisoni L, Batlle-Morera L, Bird AP, Suzuki M \& McQueen HA 2005 Femalespecific hyperacetylation of histone $\mathrm{H} 4$ in the chicken $\mathrm{Z}$ chromosome. Chromosome Research 13 205-214. (doi:10.1007/s10577-005-1505-4)

Bitgood MJ, Shen L \& McMahon AP 1996 Sertoli cell signaling by desert hedgehog regulates the male germline. Current Biology 6 298-304. (doi:10.1016/S0960-9822(02)00480-3)

Bogani D, Siggers P, Brixey R, Warr N, Beddow S, Edwards J, Williams D, Wilhelm D, Koopman P, Flavell RA et al. 2009 Loss of mitogen-activated protein kinase kinase kinase 4 (MAP3K4) reveals a requirement for MAPK signalling in mouse sex determination. PLoS Biology 7 e1000196. (doi:10.1371/journal.pbio.1000196)

Bowles J \& Koopman P 2010 Sex determination in mammalian germ cells: extrinsic versus intrinsic factors. Reproduction 139 943-958. (doi:10. 1530/REP-10-0075)

Bowles J, Schepers G \& Koopman P 2000 Phylogeny of the SOX family of developmental transcription factors based on sequence and structural indicators. Developmental Biology 227 239-255. (doi:10.1006/dbio. 2000.9883)
Brennecke J, Aravin AA, Stark A, Dus M, Kellis M, Sachidanandam R \& Hannon GJ 2007 Discrete small RNA-generating loci as master regulators of transposon activity in Drosophila. Cell 128 1089-1103. (doi:10.1016/j.cell.2007.01.043)

Buaas FW, Val P \& Swain A 2009 The transcription co-factor CITED2 functions during sex determination and early gonad development. Human Molecular Genetics 18 2989-3001. (doi:10.1093/hmg/ddp237)

Bullejos M \& Koopman P 2001 Spatially dynamic expression of Sry in mouse genital ridges. Developmental Dynamics 221 201-205. (doi:10.1002/dvdy.1134)

Bullejos M \& Koopman P 2004 Germ cells enter meiosis in a rostro-caudal wave during development of the mouse ovary. Molecular Reproduction and Development 68 422-428. (doi:10.1002/mrd.20105)

Byskov AG 1986 Differentiation of mammalian embryonic gonad. Physiological Reviews 66 71-117.

Capel B, Swain A, Nicolis S, Hacker A, Walter M, Koopman P, Goodfellow P \& Lovell-Badge R 1993 Circular transcripts of the testisdetermining gene Sry in adult mouse testis. Cell 73 1019-1030. (doi:10. 1016/0092-8674(93)90279-Y)

Capel B, Albrecht KH, Washburn LL \& Eicher EM 1999 Migration of mesonephric cells into the mammalian gonad depends on Sry. Mechanisms of Development 84 127-131. (doi:10.1016/S0925-4773 (99)00047-7)

Carmell MA, Girard A, van de Kant HJ, Bourc'his D, Bestor TH, de Rooij DG \& Hannon GJ 2007 MIWI2 is essential for spermatogenesis and repression of transposons in the mouse male germline. Developmental Cell 12 503-514. (doi:10.1016/j.devcel.2007.03.001)

Carninci P, Kasukawa T, Katayama S, Gough J, Frith MC, Maeda N, Oyama R, Ravasi T, Lenhard B, Wells C et al. 2005 The transcriptional landscape of the mammalian genome. Science 309 1559-1563. (doi:10. 1126/science.1112014)

Carthew RW \& Sontheimer EJ 2009 Origins and mechanisms of miRNAs and siRNAs. Cell 136 642-655. (doi:10.1016/j.cell.2009.01.035)

Chen $\mathbf{H}$, Palmer JS, Thiagarajan RD, Dinger ME, Lesieur E, Chiu $\mathbf{H}$, Schulz A, Spiller C, Grimmond SM, Little MH et al. 2012 Identification of novel markers of mouse fetal ovary development. PLOS ONE 7 e41683. (doi:10.1371/journal.pone.0041683)

Cheng LC, Pastrana E, Tavazoie M \& Doetsch F 2009 miR-124 regulates adult neurogenesis in the subventricular zone stem cell niche. Nature Neuroscience 12 399-408. (doi:10.1038/nn.2294)

Chue J \& Smith CA 2011 Sex determination and sexual differentiation in the avian model. FEBS Journal 278 1027-1034. (doi:10.1111/j.1742-4658. 2011.08032.x)

Ciaudo C, Servant N, Cognat V, Sarazin A, Kieffer E, Viville S, Colot V, Barillot E, Heard E \& Voinnet O 2009 Highly dynamic and sex-specific expression of microRNAs during early ES cell differentiation. PLOS Genetics 5 e1000620. (doi:10.1371/journal.pgen.1000620)

Clark JM \& Eddy EM 1975 Fine structural observations on the origin and associations of primordial germ cells of the mouse. Developmental Biology 47 136-155. (doi:10.1016/0012-1606(75)90269-9)

Clark AM, Garland KK \& Russell LD 2000 Desert hedgehog (Dhh) gene is required in the mouse testis for formation of adult-type Leydig cells and normal development of peritubular cells and seminiferous tubules. Biology of Reproduction 63 1825-1838. (doi:10.1095/biolreprod63. 6.1825)

Combes AN, Wilhelm D, Davidson T, Dejana E, Harley V, Sinclair A \& Koopman P 2009 Endothelial cell migration directs testis cord formation. Developmental Biology 326 112-120. (doi:10.1016/j.ydbio.2008. 10.040)

Consortium EP, Birney E, Stamatoyannopoulos JA, Dutta A, Guigo R, Gingeras TR, Margulies EH, Weng Z, Snyder M, Dermitzakis ET et al. 2007 Identification and analysis of functional elements in $1 \%$ of the human genome by the ENCODE pilot project. Nature 447 799-816. (doi:10.1038/nature05874)

Cool J, Carmona FD, Szucsik JC \& Capel B 2008 Peritubular myoid cells are not the migrating population required for testis cord formation in the $\mathrm{XY}$ gonad. Sexual Development 2 128-133. (doi:10.1159/000143430)

Cox DN, Chao A, Baker J, Chang L, Qiao D \& Lin H 1998 A novel class of evolutionarily conserved genes defined by piwi are essential for stem cell self-renewal. Genes and Development 12 3715-3727. (doi:10.1101/ gad.12.23.3715) 
Cutting A, Chue J \& Smith CA 2013 Just how conserved is vertebrate sex determination? Developmental Dynamics 242 380-387. (doi:10.1002/ dvdy.23944)

Deng W \& Lin H 2002 miwi, a murine homolog of piwi, encodes a cytoplasmic protein essential for spermatogenesis. Developmental Cell 2 819-830. (doi:10.1016/S1534-5807(02)00165-X)

Donovan PJ, Stott D, Cairns LA, Heasman J \& Wylie CC 1986 Migratory and postmigratory mouse primordial germ cells behave differently in culture. Cell 44 831-838. (doi:10.1016/0092-8674(86)90005-X)

Eggers S, Ohnesorg T \& Sinclair A 2014 Genetic regulation of mammalian gonad development. Nature Reviews. Endocrinology 10 673-683. (doi:10.1038/nrendo.2014.163)

Eik-Nes KB 1969 An effect of isoproterenol on rates of synthesis and secretion of testosterone. American Journal of Physiology 217 1764-1770.

Elbrecht A \& Smith RG 1992 Aromatase enzyme activity and sex determination in chickens. Science 255 467-470. (doi:10.1126/science. 1734525)

Farazi TA, Juranek SA \& Tuschl T 2008 The growing catalog of small RNAs and their association with distinct Argonaute/Piwi family members. Development 135 1201-1214. (doi:10.1242/dev.005629)

Fatica A \& Bozzoni I 2014 Long non-coding RNAs: new players in cell differentiation and development. Nature Reviews. Genetics 15 7-21. (doi:10.1038/nrg3606)

Filipowicz W, Bhattacharyya SN \& Sonenberg N 2008 Mechanisms of posttranscriptional regulation by microRNAs: are the answers in sight? Nature Reviews. Genetics 9 102-114. (doi:10.1038/nrg2290)

Gamble T \& Zarkower D 2012 Sex determination. Current Biology 22 R257-R262. (doi:10.1016/j.cub.2012.02.054)

Gierl MS, Gruhn WH, von Seggern A, Maltry N \& Niehrs C 2012 GADD45G functions in male sex determination by promoting p38 signaling and Sry expression. Developmental Cell 23 1032-1042. (doi:10.1016/j.devcel.2012.09.014)

Ginsburg M, Snow MH \& McLaren A 1990 Primordial germ cells in the mouse embryo during gastrulation. Development 110 521-528.

Girard A, Sachidanandam R, Hannon GJ \& Carmell MA 2006 A germlinespecific class of small RNAs binds mammalian Piwi proteins. Nature $\mathbf{4 4 2}$ 199-202. (doi:10.1038/nature04917)

Golden DE, Gerbasi VR \& Sontheimer EJ 2008 An inside job for siRNAs. Molecular Cell 31 309-312. (doi:10.1016/j.molcel.2008.07.008)

Gonzalez G \& Behringer RR 2009 Dicer is required for female reproductive tract development and fertility in the mouse. Molecular Reproduction and Development 76 678-688. (doi:10.1002/mrd.21010)

Grimson A, Srivastava M, Fahey B, Woodcroft BJ, Chiang HR, King N, Degnan BM, Rokhsar DS \& Bartel DP 2008 Early origins and evolution of microRNAs and Piwi-interacting RNAs in animals. Nature 455 1193-1197. (doi:10.1038/nature07415)

Grivna ST, Beyret E, Wang Z \& Lin H 2006 A novel class of small RNAs in mouse spermatogenic cells. Genes and Development 20 1709-1714. (doi:10.1101/gad.1434406)

Guttman M, Donaghey J, Carey BW, Garber M, Grenier JK, Munson G, Young G, Lucas AB, Ach R, Bruhn L et al. 2011 lincRNAs act in the circuitry controlling pluripotency and differentiation. Nature $\mathbf{4 7 7}$ 295-300. (doi:10.1038/nature10398)

Ha H, Song J, Wang S, Kapusta A, Feschotte C, Chen KC \& Xing J 2014 A comprehensive analysis of piRNAs from adult human testis and their relationship with genes and mobile elements. BMC Genomics 15545. (doi:10.1186/1471-2164-15-545)

Hacker A, Capel B, Goodfellow P \& Lovell-Badge R 1995 Expression of Sry, the mouse sex determining gene. Development 121 1603-1614.

Hammes A, Guo JK, Lutsch G, Leheste JR, Landrock D, Ziegler U, Gubler MC \& Schedl A 2001 Two splice variants of the Wilms' tumor 1 gene have distinct functions during sex determination and nephron formation. Cell 106 319-329. (doi:10.1016/S0092-8674(01)00453-6)

Hansen TB, Jensen TI, Clausen BH, Bramsen JB, Finsen B, Damgaard CK \& Kjems J 2013a Natural RNA circles function as efficient microRNA sponges. Nature 495 384-388. (doi:10.1038/nature11993)

Hansen TB, Kjems J \& Damgaard CK $2013 b$ Circular RNA and miR-7 in cancer. Cancer Research 73 5609-5612. (doi:10.1158/0008-5472.CAN13-1568)

Hattori RS, Murai Y, Oura M, Masuda S, Majhi SK, Sakamoto T, Fernandino J, Somoza GM, Yokota M \& Strussmann CA 2012 A
Y-linked anti-Mullerian hormone duplication takes over a critical role in sex determination. PNAS 109 2955-2959. (doi:10.1073/pnas.101 8392109)

Hayashi K, Chuva de Sousa Lopes SM, Kaneda M, Tang F, Tang P, Hajkova P, Lao K, O'Carr D, Das PP, Tarakhovsky A et al. 2008 MicroRNA biogenesis is required for mouse primordial germ cell development and spermatogenesis. PLoS ONE 3 e1738. (doi:10.1371/journal.pone. 0001738)

He L, Thomson JM, Hemann MT, Hernando-Monge E, Mu D, Goodson S, Powers S, Cordon-Cardo C, Lowe SW, Hannon GJ et al. 2005 A microRNA polycistron as a potential human oncogene. Nature 435 828-833. (doi:10.1038/nature03552)

Heo I, Joo C, Cho J, Ha M, Han J \& Kim VN 2008 Lin28 mediates the terminal uridylation of let-7 precursor MicroRNA. Molecular Cell 32 276-284. (doi:10.1016/j.molcel.2008.09.014)

Hong X, Luense LJ, McGinnis LK, Nothnick WB \& Christenson LK 2008 Dicer1 is essential for female fertility and normal development of the female reproductive system. Endocrinology 149 6207-6212. (doi:10.1210/en.2008-0294)

Houwing S, Kamminga LM, Berezikov E, Cronembold D, Girard A, van den Elst H, Filippov DV, Blaser H, Raz E, Moens CB et al. 2007 A role for Piwi and piRNAs in germ cell maintenance and transposon silencing in Zebrafish. Cell 129 69-82. (doi:10.1016/j.cell.2007.03.026)

Huang CC \& Yao HH 2010 Inactivation of Dicer1 in steroidogenic factor 1-positive cells reveals tissue-specific requirement for Dicer1 in adrenal, testis, and ovary. BMC Developmental Biology 10 66. (doi:10.1186/ 1471-213X-10-66)

Huang X, Guo Y, Shui Y, Gao S, Yu H, Cheng H \& Zhou R 2005 Multiple alternative splicing and differential expression of dmrt1 during gonad transformation of the rice field eel. Biology of Reproduction 73 1017-1024. (doi:10.1095/biolreprod.105.041871)

Jeck WR \& Sharpless NE 2014 Detecting and characterizing circular RNAs. Nature biotechnology 32 453-461. (doi:10.1038/nbt.2890)

Jeck WR, Sorrentino JA, Wang K, Slevin MK, Burd CE, Liu J, Marzluff WF \& Sharpless NE 2013 Circular RNAs are abundant, conserved, and associated with ALU repeats. RNA 19 141-157. (doi:10.1261/rna. 035667.112)

Kalmykova Al, Klenov MS \& Gvozdev VA 2005 Argonaute protein PIWI controls mobilization of retrotransposons in the Drosophila male germline. Nucleic Acids Research 33 2052-2059. (doi:10.1093/nar/ gki323)

Katoh-Fukui Y, Miyabayashi K, Komatsu T, Owaki A, Baba T, Shima Y, Kidokoro T, Kanai Y, Schedl A, Wilhelm D et al. 2012 Cbx2, a polycomb group gene, is required for Sry gene expression in mice. Endocrinology 153 913-924. (doi:10.1210/en.2011-1055)

Kawaoka S, Kadota K, Arai Y, Suzuki Y, Fujii T, Abe H, Yasukochi Y, Mita K, Sugano S, Shimizu K et al. 2011 The silkworm W chromosome is a source of female-enriched piRNAs. RNA 17 2144-2151. (doi:10.1261/ rna.027565.111)

Kefas B, Godlewski J, Comeau L, Li Y, Abounader R, Hawkinson M, Lee J, Fine $\mathbf{H}$, Chiocca EA, Lawler S et al. 2008 microRNA-7 inhibits the epidermal growth factor receptor and the Akt pathway and is downregulated in glioblastoma. Cancer Research 68 3566-3572. (doi:10.1158/0008-5472.CAN-07-6639)

Kim Y, Bingham N, Sekido R, Parker KL, Lovell-Badge R \& Capel B 2007 Fibroblast growth factor receptor 2 regulates proliferation and Sertoli differentiation during male sex determination. PNAS 104 16558-16563. (doi:10.1073/pnas.0702581104)

Kim VN, Han J \& Siomi MC 2009 Biogenesis of small RNAs in animals. Nature Reviews. Molecular Cell Biology 10 126-139. (doi:10.1038/ nrm2632)

Kim TH, Yun TW, Rengaraj D, Lee SI, Lim SM, Seo HW, Park TS \& Han JY 2012 Conserved functional characteristics of the PIWI family members in chicken germ cell lineage. Theriogenology 78 1948-1959. (doi:10.1016/ j.theriogenology.2012.07.019)

Kiuchi T, Koga H, Kawamoto M, Shoji K, Sakai H, Arai Y, Ishihara G, Kawaoka S, Sugano S, Shimada T et al. 2014 A single female-specific piRNA is the primary determiner of sex in the silkworm. Nature 509 633-636. (doi:10.1038/nature13315)

Klattenhoff C \& Theurkauf W 2008 Biogenesis and germline functions of piRNAs. Development 135 3-9. (doi:10.1242/dev.006486) 
Kobayashi A, Chang H, Chaboissier MC, Schedl A \& Behringer RR 2005 Sox9 in testis determination. Annals of the New York Academy of Sciences 1061 9-17. (doi:10.1196/annals.1336.003)

Kuramochi-Miyagawa S, Kimura T, Ijiri TW, Isobe T, Asada N, Fujita Y, Ikawa M, Iwai N, Okabe M, Deng W et al. 2004 Mili, a mammalian member of piwi family gene, is essential for spermatogenesis. Development 131 839-849. (doi:10.1242/dev.00973)

Kuramochi-Miyagawa S, Watanabe T, Gotoh K, Takamatsu K, Chuma S, Kojima-Kita K, Shiromoto Y, Asada N, Toyoda A, Fujiyama A et al. 2010 $\mathrm{MVH}$ in piRNA processing and gene silencing of retrotransposons. Genes and Development 24 887-892. (doi:10.1101/gad.1902110)

Lambeth LS, Raymond CS, Roeszler KN, Kuroiwa A, Nakata T, Zarkower D \& Smith CA 2014 Over-expression of DMRT1 induces the male pathway in embryonic chicken gonads. Developmental Biology 389 160-172. (doi:10.1016/j.ydbio.2014.02.012)

Lau NC, Seto AG, Kim J, Kuramochi-Miyagawa S, Nakano T, Bartel DP \& Kingston RE 2006 Characterization of the piRNA complex from rat testes. Science 313 363-367. (doi:10.1126/science.1130164)

Lawson KA \& Hage WJ 1994 Clonal analysis of the origin of primordial germ cells in the mouse. Ciba Foundation symposium 182 68-84 discussion 84-91.

Li Y, Wang HY, Wan FC, Liu FJ, Liu J, Zhang N, Jin SH \& Li JY 2012 Deep sequencing analysis of small non-coding RNAs reveals the diversity of microRNAs and piRNAs in the human epididymis. Gene 497 330-335. (doi:10.1016/j.gene.2012.01.038)

Li XZ, Roy CK, Moore MJ \& Zamore PD 2013 Defining piRNA primary transcripts. Cell Cycle 12 1657-1658. (doi:10.4161/cc.24989)

Lim SL, Tsend-Ayush E, Kortschak RD, Jacob R, Ricciardelli C, Oehler MK \& Grutzner F 2013 Conservation and expression of PIWl-interacting RNA pathway genes in male and female adult gonad of amniotes. Biology of Reproduction 89 136. (doi:10.1095/biolreprod.113.111211)

Lin H \& Spradling AC 1997 A novel group of pumilio mutations affects the asymmetric division of germline stem cells in the Drosophila ovary. Development 124 2463-2476.

Luo X, Ikeda Y \& Parker KL 1994 A cell-specific nuclear receptor is essential for adrenal and gonadal development and sexual differentiation. Cell 77 481-490. (doi:10.1016/0092-8674(94)90211-9)

Maatouk DM, Loveland KL, McManus MT, Moore K \& Harfe BD 2008 Dicer 1 is required for differentiation of the mouse male germline. Biology of Reproduction 79 696-703. (doi:10.1095/biolreprod.108.067827)

Malki S, Nef S, Notarnicola C, Thevenet L, Gasca S, Mejean C, Berta P, Poulat F \& Boizet-Bonhoure B 2005 Prostaglandin D2 induces nuclear import of the sex-determining factor SOX9 via its CAMP-PKA phosphorylation. EMBO Journal 24 1798-1809. (doi:10.1038/sj.emboj.7600660)

Malone CD \& Hannon GJ 2009 Small RNAs as guardians of the genome. Cell 136 656-668. (doi:10.1016/j.cell.2009.01.045)

Marshall Graves JA 2008 Weird animal genomes and the evolution of vertebrate sex and sex chromosomes. Annual Review of Genetics 42 565-586. (doi:10.1146/annurev.genet.42.110807.091714)

Martineau J, Nordqvist K, Tilmann C, Lovell-Badge R \& Capel B 1997 Malespecific cell migration into the developing gonad. Current Biology 7 958-968. (doi:10.1016/S0960-9822(06)00415-5)

Matson CK \& Zarkower D 2012 Sex and the singular DM domain: insights into sexual regulation, evolution and plasticity. Nature Reviews. Genetics 13 163-174. (doi:10.1038/nrg3161)

Matsuda M, Nagahama Y, Shinomiya A, Sato T, Matsuda C, Kobayashi T, Morrey CE, Shibata N, Asakawa S, Shimizu N et al. 2002 DMY is a $\mathrm{Y}$-specific DM-domain gene required for male development in the medaka fish. Nature 417 559-563. (doi:10.1038/nature751)

Melamed E \& Arnold AP 2007 Regional differences in dosage compensation on the chicken Z chromosome. Genome Biology 8 R202. (doi:10.1186/ gb-2007-8-9-r202)

Memczak S, Jens M, Elefsinioti A, Torti F, Krueger J, Rybak A, Maier L, Mackowiak SD, Gregersen LH, Munschauer M et al. 2013 Circular RNAs are a large class of animal RNAs with regulatory potency. Nature 495 333-338. (doi:10.1038/nature11928)

Mercer TR, Dinger ME \& Mattick JS 2009 Long non-coding RNAs: insights into functions. Nature Reviews. Genetics 10 155-159. (doi:10.1038/nrg2521)

Mercer TR, Wilhelm D, Dinger ME, Solda G, Korbie DJ, Glazov EA, Truong V, Schwenke M, Simons C, Matthaei KI et al. 2011 Expression of distinct RNAs from $3^{\prime}$ untranslated regions. Nucleic Acids Research 39 2393-2403. (doi:10.1093/nar/gkq1158)
Michalak P \& Malone JH 2008 Testis-derived microRNA profiles of African clawed frogs (Xenopus) and their sterile hybrids. Genomics 91 158-164. (doi:10.1016/j.ygeno.2007.10.013)

Miyamoto N, Yoshida M, Kuratani S, Matsuo I \& Aizawa S 1997 Defects of urogenital development in mice lacking Emx2. Development 124 1653-1664

Moniot B, Declosmenil F, Barrionuevo F, Scherer G, Aritake K, Malki S, Marzi L, Cohen-Solal A, Georg I, Klattig J et al. 2009 The PGD2 pathway, independently of FGF9, amplifies SOX9 activity in Sertoli cells during male sexual differentiation. Development 136 1813-1821. (doi:10.1242/dev.032631)

Morais da Silva S, Hacker A, Harley V, Goodfellow P, Swain A \& LovellBadge R 1996 Sox9 expression during gonadal development implies a conserved role for the gene in testis differentiation in mammals and birds. Nature Genetics 14 62-68. (doi:10.1038/ng0996-62)

Moran VA, Perera RJ \& Khalil AM 2012 Emerging functional and mechanistic paradigms of mammalian long non-coding RNAs. Nucleic Acids Research 40 6391-6400. (doi:10.1093/nar/gks296)

Murchison EP, Kheradpour P, Sachidanandam R, Smith C, Hodges E, Xuan Z, Kellis M, Grutzner F, Stark A \& Hannon GJ 2008 Conservation of small RNA pathways in platypus. Genome Research 18 995-1004. (doi:10.1101/gr.073056.107)

Nagaraja AK, Andreu-Vieyra C, Franco HL, Ma L, Chen R, Han DY, Zhu H, Agno JE, Gunaratne PH, DeMayo FJ et al. 2008 Deletion of Dicer in somatic cells of the female reproductive tract causes sterility. Molecular Endocrinology 22 2336-2352. (doi:10.1210/me.2008-0142)

Nakamura Y, Yamamoto K, He X, Otsuki B, Kim Y, Murao H, Soeda T, Tsumaki N, Deng JM, Zhang Z et al. 2011 Wwp2 is essential for palatogenesis mediated by the interaction between Sox 9 and mediator subunit 25. Nature Communications 2 251. (doi:10.1038/ncomms1242)

Nef S, Verma-Kurvari S, Merenmies J, Vassalli JD, Efstratiadis A, Accili D \& Parada LF 2003 Testis determination requires insulin receptor family function in mice. Nature 426 291-295. (doi:10.1038/nature02059)

Nie K, Gomez M, Landgraf P, Garcia JF, Liu Y, Tan LH, Chadburn A, Tuschl T, Knowles DM \& Tam W 2008 MicroRNA-mediated downregulation of PRDM1/Blimp-1 in Hodgkin/Reed-Sternberg cells: a potential pathogenetic lesion in Hodgkin lymphomas. American Journal of Pathology 173 242-252. (doi:10.2353/ajpath.2008.080009)

Ohinata Y, Payer B, O'Carroll D, Ancelin K, Ono Y, Sano M, Barton SC, Obukhanych T, Nussenzweig M, Tarakhovsky A et al. 2005 Blimp1 is a critical determinant of the germ cell lineage in mice. Nature $\mathbf{4 3 6}$ 207-213. (doi:10.1038/nature03813)

Okazaki Y, Furuno M, Kasukawa T, Adachi J, Bono H, Kondo S, Nikaido I, Osato N, Saito R, Suzuki H et al. 2002 Analysis of the mouse transcriptome based on functional annotation of 60,770 full-length cDNAs. Nature 420 563-573. (doi:10.1038/nature01266)

O'Shaughnessy PJ, Baker PJ, Monteiro A, Cassie S, Bhattacharya S \& Fowler PA 2007 Developmental changes in human fetal testicular cell numbers and messenger ribonucleic acid levels during the second trimester. Journal of Clinical Endocrinology and Metabolism 92 4792-4801. (doi:10.1210/jc.2007-1690)

Papaioannou MD, Pitetti JL, Ro S, Park C, Aubry F, Schaad O, Vejnar CE, Kuhne F, Descombes P, Zdobnov EM et al. 2009 Sertoli cell Dicer is essential for spermatogenesis in mice. Developmental Biology 326 250-259. (doi:10.1016/j.ydbio.2008.11.011)

Park CY, Jeker LT, Carver-Moore K, Oh A, Liu HJ, Cameron R, Richards H, Li Z, Adler D, Yoshinaga $Y$ et al. 2012 A resource for the conditional ablation of microRNAs in the mouse. Cell Reports 1 385-391. (doi:10. 1016/j.celrep.2012.02.008)

Pillai RS 2005 MicroRNA function: multiple mechanisms for a tiny RNA? RNA 11 1753-1761. (doi:10.1261/rna.2248605)

Pilon N, Daneau I, Paradis V, Hamel F, Lussier JG, Viger RS \& Silversides DW 2003 Porcine SRY promoter is a target for steroidogenic factor 1. Biology of Reproduction 68 1098-1106. (doi:10.1095/ biolreprod.102.010884)

Pitetti JL, Calvel P, Romero Y, Conne B, Truong V, Papaioannou MD, Schaad O, Docquier M, Herrera PL, Wilhelm D et al. 2013 Insulin and IGF1 receptors are essential for $X X$ and $X Y$ gonadal differentiation and adrenal development in mice. PLoS Genetics 9 e1003160. (doi:10.1371/ journal.pgen.1003160)

Rakoczy J, Fernandez-Valverde SL, Glazov EA, Wainwright EN, Sato T, Takada S, Combes AN, Korbie DJ, Miller D, Grimmond SM et al. 2013 
MicroRNAs-140-5p/140-3p modulate Leydig cell numbers in the developing mouse testis. Biology of Reproduction 88 143. (doi:10. 1095/biolreprod.113.107607)

Raymond CS, Murphy MW, O'Sullivan MG, Bardwell VJ \& Zarkower D 2000 Dmrt1, a gene related to worm and fly sexual regulators, is required for mammalian testis differentiation. Genes and Development $\mathbf{1 4}$ 2587-2595. (doi:10.1101/gad.834100)

Real FM, Sekido R, Lupianez DG, Lovell-Badge R, Jimenez R \& Burgos M 2013 A microRNA (mmu-miR-124) prevents Sox9 expression in developing mouse ovarian cells. Biology of Reproduction 8978. (doi:10.1095/biolreprod.113.110957)

Rengaraj D, Lee SI, Park TS, Lee HJ, Kim YM, Sohn YA, Jung M, Noh SJ, Jung H \& Han JY 2014 Small non-coding RNA profiling and the role of piRNA pathway genes in the protection of chicken primordial germ cells. BMC Genomics 15 757. (doi:10.1186/1471-2164-15-757)

Robine N, Lau NC, Balla S, Jin Z, Okamura K, Kuramochi-Miyagawa S, Blower MD \& Lai EC 2009 A broadly conserved pathway generates 3'UTR-directed primary piRNAs. Current Biology 19 2066-2076. (doi:10.1016/j.cub.2009.11.064)

Roeszler KN, Itman C, Sinclair AH \& Smith CA 2012 The long non-coding RNA, MHM, plays a role in chicken embryonic development, including gonadogenesis. Developmental Biology 366 317-326. (doi:10.1016/j. ydbio.2012.03.025)

Rougvie AE 2001 Control of developmental timing in animals. Nature Reviews. Genetics 2 690-701. (doi:10.1038/35088566)

Ruby JG, Jan C, Player C, Axtell MJ, Lee W, Nusbaum C, Ge H \& Bartel DP 2006 Large-scale sequencing reveals 21U-RNAs and additional microRNAs and endogenous siRNAs in C. elegans. Cell 127 1193-1207. (doi:10.1016/j.cell.2006.10.040)

Rybak A, Fuchs H, Smirnova L, Brandt C, Pohl EE, Nitsch R \& Wulczyn FG 2008 A feedback loop comprising lin-28 and let-7 controls pre-let-7 maturation during neural stem-cell commitment. Nature Cell Biology $\mathbf{1 0}$ 987-993. (doi:10.1038/ncb1759)

Sadovsky Y, Crawford PA, Woodson KG, Polish JA, Clements MA, Tourtellotte LM, Simburger K \& Milbrandt J 1995 Mice deficient in the orphan receptor steroidogenic factor 1 lack adrenal glands and gonads but express P450 side-chain-cleavage enzyme in the placenta and have normal embryonic serum levels of corticosteroids. PNAS 92 10939-10943. (doi:10.1073/pnas.92.24.10939)

Salzman J, Gawad C, Wang PL, Lacayo N \& Brown PO 2012 Circular RNAs are the predominant transcript isoform from hundreds of human genes in diverse cell types. PLOS ONE 7 e30733. (doi:10.1371/journal.pone. 0030733)

Sanuki R, Onishi A, Koike C, Muramatsu R, Watanabe S, Muranishi Y, Irie S, Uneo S, Koyasu T, Matsui R et al. 2011 miR-124a is required for hippocampal axogenesis and retinal cone survival through Lhx2 suppression. Nature Neuroscience 14 1125-1134. (doi:10.1038/nn. 2897)

Schmahl J \& Capel B 2003 Cell proliferation is necessary for the determination of male fate in the gonad. Developmental Biology 258 264-276. (doi:10.1016/S0012-1606(03)00122-2)

Schmahl J, Eicher E, Washburn L \& Capel B 2000 Sry induces cell proliferation in the mouse gonad. Development 127 65-73.

Schnabel CA, Selleri L \& Cleary ML 2003 Pbx1 is essential for adrenal development and urogenital differentiation. Genesis 37 123-130. (doi:10.1002/gene.10235)

Sekido R \& Lovell-Badge R 2008 Sex determination involves synergistic action of SRY and SF1 on a specific Sox9 enhancer. Nature 453 930-934. (doi:10.1038/nature06944)

Sekido R, Bar I, Narvaez V, Penny G \& Lovell-Badge R 2004 SOX9 is upregulated by the transient expression of SRY specifically in Sertoli cell precursors. Developmental Biology 274 271-279. (doi:10.1016/j.ydbio. 2004.07.011)

Shoemaker C, Ramsey M, Queen J \& Crews D 2007a Expression of Sox9, Mis, and Dmrt1 in the gonad of a species with temperature-dependent sex determination. Developmental Dynamics 236 1055-1063. (doi:10. 1002/dvdy.21096)

Shoemaker CM, Queen J \& Crews D $2007 b$ Response of candidate sexdetermining genes to changes in temperature reveals their involvement in the molecular network underlying temperature-dependent sex determination. Molecular Endocrinology 21 2750-2763. (doi:10.1210/ me.2007-0263)
Smith CA, McClive PJ, Western PS, Reed KJ \& Sinclair AH 1999 Conservation of a sex-determining gene. Nature 402 601-602. (doi:10. 1038/45130)

Smith CA, Roeszler KN, Ohnesorg T, Cummins DM, Farlie PG, Doran TJ \& Sinclair AH 2009 The avian Z-linked gene DMRT1 is required for male sex determination in the chicken. Nature 461 267-271. (doi:10.1038/ nature08298)

Smyk M, Szafranski P, Startek M, Gambin A \& Stankiewicz P 2013 Chromosome conformation capture-on-chip analysis of long-range cisinteractions of the SOX9 promoter. Chromosome Research 21 781-788. (doi:10.1007/s10577-013-9386-4)

Song R, Hennig GW, Wu Q, Jose C, Zheng H \& Yan W 2011 Male germ cells express abundant endogenous siRNAs. PNAS 108 13159-13164. (doi:10.1073/pnas.1108567108)

Svingen T \& Koopman P 2013 Building the mammalian testis: origins, differentiation, and assembly of the component cell populations. Genes and Development 27 2409-2426. (doi:10.1101/gad.228080.113)

Tam OH, Aravin AA, Stein P, Girard A, Murchison EP, Cheloufi S, Hodges E, Anger M, Sachidanandam R, Schultz RM et al. 2008 Pseudogenederived small interfering RNAs regulate gene expression in mouse oocytes. Nature 453 534-538. (doi:10.1038/nature06904)

Tang H, Brennan J, Karl J, Hamada Y, Raetzman L \& Capel B 2008 Notch signaling maintains Leydig progenitor cells in the mouse testis. Development 135 3745-3753. (doi:10.1242/dev.024786)

Teranishi M, Shimada Y, Hori T, Nakabayashi O, Kikuchi T, Macleod T, Pym R, Sheldon B, Solovei I, Macgregor H et al. 2001 Transcripts of the MHM region on the chicken $Z$ chromosome accumulate as non-coding RNA in the nucleus of female cells adjacent to the DMRT1 locus. Chromosome Research 9 147-165. (doi:10.1023/A:1009235120741)

Tevosian SG, Albrecht KH, Crispino JD, Fujiwara Y, Eicher EM \& Orkin SH 2002 Gonadal differentiation, sex determination and normal Sry expression in mice require direct interaction between transcription partners GATA4 and FOG2. Development 129 4627-4634.

Tung PS, Skinner MK \& Fritz IB 1984 Cooperativity between Sertoli cells and peritubular myoid cells in the formation of the basal lamina in the seminiferous tubule. Annals of the New York Academy of Sciences 438 435-446. (doi:10.1111/j.1749-6632.1984.tb38304.x)

Ulitsky I \& Bartel DP 2013 lincRNAs: genomics, evolution, and mechanisms. Cell 154 26-46. (doi:10.1016/j.cell.2013.06.020)

Vagin VV, Sigova A, Li C, Seitz H, Gvozdev V \& Zamore PD 2006 A distinct small RNA pathway silences selfish genetic elements in the germline. Science 313 320-324. (doi:10.1126/science.1129333)

Vincent SD, Dunn NR, Sciammas R, Shapiro-Shalef M, Davis MM, Calame K, Bikoff EK \& Robertson EJ 2005 The zinc finger transcriptional repressor Blimp1/Prdm1 is dispensable for early axis formation but is required for specification of primordial germ cells in the mouse. Development 132 1315-1325. (doi:10.1242/dev.01711)

Viswanathan SR, Daley GQ \& Gregory RI 2008 Selective blockade of microRNA processing by Lin28. Science 320 97-100. (doi:10.1126/ science.1154040)

Wainwright EN, Jorgensen JS, Kim Y, Truong V, Bagheri-Fam S, Davidson T, Svingen T, Fernandez-Valverde SL, McClelland KS, Taft RJ et al. 2013 SOX9 regulates microRNA miR-202-5p/3p expression during mouse testis differentiation. Biology of Reproduction 89 34. (doi:10.1095/ biolreprod.113.110155)

Wang Q, Lan Y, Cho ES, Maltby KM \& Jiang R 2005 Odd-skipped related 1 (Odd 1) is an essential regulator of heart and urogenital development. Developmental Biology 288 582-594. (doi:10.1016/j.ydbio.2005. 09.024)

Warr N, Carre GA, Siggers P, Faleato JV, Brixey R, Pope M, Bogani D, Childers M, Wells S, Scudamore CL et al. 2012 Gadd $45 \gamma$ and Map3k4 interactions regulate mouse testis determination via p38 MAPK-mediated control of Sry expression. Developmental Cell 23 1020-1031. (doi:10. 1016/j.devcel.2012.09.016)

Watanabe T, Takeda A, Tsukiyama T, Mise K, Okuno T, Sasaki H, Minami N \& Imai H 2006 Identification and characterization of two novel classes of small RNAs in the mouse germline: retrotransposon-derived siRNAs in oocytes and germline small RNAs in testes. Genes and Development 20 1732-1743. (doi:10.1101/gad.1425706)

Weick EM \& Miska EA 2014 piRNAs: from biogenesis to function. Development 141 3458-3471. (doi:10.1242/dev.094037) 
West JA, Viswanathan SR, Yabuuchi A, Cunniff K, Takeuchi A, Park IH, Sero JE, Zhu H, Perez-Atayde A, Frazier AL et al. 2009 A role for Lin28 in primordial germ-cell development and germ-cell malignancy. Nature 460 909-913. (doi:10.1038/nature08210)

Western PS, Harry JL, Graves JA \& Sinclair AH 1999 Temperaturedependent sex determination: upregulation of SOX9 expression after commitment to male development. Developmental Dynamics 214 171-177. (doi:10.1002/(SICl)1097-0177(199903)214:3<171::AIDAJA1 > 3.0.CO;2-S)

Western PS, Miles DC, van den Bergen JA, Burton M \& Sinclair AH 2008 Dynamic regulation of mitotic arrest in fetal male germ cells. Stem Cells 26 339-347. (doi:10.1634/stemcells.2007-0622)

Whitworth C \& Oliver B 2014 Flipping the doublesex switch with a piRNA. Genome Biology 15 118. (doi:10.1186/gb4181)

Wilhelm D, Martinson F, Bradford S, Wilson MJ, Combes AN, Beverdam A, Bowles J, Mizusaki H \& Koopman P 2005 Sertoli cell differentiation is induced both cell-autonomously and through prostaglandin signaling during mammalian sex determination. Developmental Biology 287 111-124. (doi:10.1016/j.ydbio.2005.08.039)

Wilhelm D, Hiramatsu R, Mizusaki H, Widjaja L, Combes AN, Kanai Y \& Koopman P 2007 SOX9 regulates prostaglandin D synthase gene transcription in vivo to ensure testis development. Journal of Biological Chemistry 282 10553-10560. (doi:10.1074/jbc.M609578200)

Wu Z, Liu X, Liu L, Deng H, Zhang J, Xu Q, Cen B \& Ji A 2014 Regulation of IncRNA expression. Cellular \& Molecular Biology Letters 19 561-575. (doi:10.2478/s11658-014-0212-6)

Yamaji M, Seki Y, Kurimoto K, Yabuta Y, Yuasa M, Shigeta M, Yamanaka K, Ohinata Y \& Saitou M 2008 Critical function of Prdm14 for the establishment of the germ cell lineage in mice. Nature Genetics $\mathbf{4 0}$ 1016-1022. (doi:10.1038/ng.186)

Yang J, Qin S, Yi C, Ma G, Zhu H, Zhou W, Xiong Y, Zhu X, Wang Y, He L et al. 2011 MiR-140 is co-expressed with Wwp2-C transcript and activated by Sox9 to target Sp1 in maintaining the chondrocyte proliferation. FEBS Letters 585 2992-2997. (doi:10.1016/j.febslet.2011. 08.013)

Yang H, Wang X, Liu X, Liu X, Li L, Hu X \& Li N 2012 Cloning and expression analysis of piRNA-like RNAs: adult testis-specific small RNAs in chicken. Molecular and Cellular Biochemistry 360 347-352. (doi:10. 1007/s11010-011-1074-0)
Yang Q, Hua J, Wang L, Xu B, Zhang H, Ye N, Zhang Z, Yu D, Cooke HJ, Zhang $\mathbf{Y}$ et al. 2013 MicroRNA and piRNA profiles in normal human testis detected by next generation sequencing. PLOS ONE 8 e66809. (doi:10.1371/journal.pone.0066809)

Yano A, Guyomard R, Nicol B, Jouanno E, Quillet E, Klopp C, Cabau C, Bouchez O, Fostier A \& Guiguen Y 2012 An immune-related gene evolved into the master sex-determining gene in rainbow trout, Oncorhynchus mykiss. Current Biology 22 1423-1428. (doi:10.1016/j. cub.2012.05.045)

Yao HH, Whoriskey W \& Capel B 2002 Desert Hedgehog/Patched 1 signaling specifies fetal Leydig cell fate in testis organogenesis. Genes and Development 16 1433-1440. (doi:10.1101/gad.981202)

Yao HH, DiNapoli L \& Capel B 2004 Cellular mechanisms of sex determination in the red-eared slider turtle. Mechanisms of Development 121 1393-1401. (doi:10.1016/j.mod.2004.06.001)

Yoshimoto S, Okada E, Umemoto H, Tamura K, Uno $Y$, NishidaUmehara C, Matsuda Y, Takamatsu N, Shiba T \& Ito M 2008 A W-linked DM-domain gene, DM-W, participates in primary ovary development in Xenopus laevis. PNAS 105 2469-2474. (doi:10.1073/ pnas.0712244105)

Zhang J, Liu Q, Zhang W, Li J, Li Z, Tang Z, Li Y, Han C, Hall SH \& Zhang Y 2010 Comparative profiling of genes and miRNAs expressed in the newborn, young adult, and aged human epididymides. Acta Biochimica et Biophysica Sinica 42 145-153. (doi:10.1093/abbs/gmp116)

Zhang Y, Li J, Chen R, Dai A, Luan D, Ma T, Hua D, Chen G \& Chang G 2013 Cloning, characterization and widespread expression analysis of testicular piRNA-like chicken RNAs. Molecular Biology Reports 40 2799-2807. (doi:10.1007/s11033-012-2295-3)

Zimmermann C, Romero Y, Warnefors M, Bilican A, Borel C, Smith LB, Kotaja N, Kaessmann H \& Nef S 2014 Germ cell-specific targeting of DICER or DGCR8 reveals a novel role for endo-siRNAs in the progression of mammalian spermatogenesis and male fertility. PLOS ONE 9 e107023. (doi:10.1371/journal.pone.0107023)

Received 8 March 2015

First decision 13 April 2015

Revised manuscript received 12 May 2015

Accepted 20 May 2015 